\title{
各種動物長管骨々䯕の血管棈造
}

\author{
第 2 編 \\ 鳥類，両棲類，爬虫類の長管骨々娟主幹血管に就いて \\ 岡山大学医学部平木內科教室（主任本木潔教授） \\ 亭坟生片山茂樹 \\ 〔昭和 29 年 3 月 20 日受稿〕
}

\section{內 客目次}

第 1 章 緒 言

第 2 章実験方法

第3章自家所胃

第 1 節 鳥. 類

第 1 項 鳩

1. 大腿骨

2. 下腿骨

3. 上㳀它骨

4. 前脑骨

第 2 項 鶏

1. 大腿骨

2. 下腿骨

3. 上腕骨

4. 前腕 骨

第 3 項 雀

1. 大腿骨

2. 下腿骨

3. 上肪盈

4. 前腕 骨

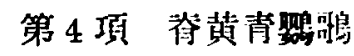

1. 大腿骨

2. 下腿骨

3. 上肪骨

4. 前腕 骨

第 2 節 画 棲 類

\section{事1草緒言}

予は酦飞家鬼を主とする哺乳類数種の長管 骨々䯣血管の主幹系飞就いて報告したが，引 緮き鳥類, 両棲類, 爬虫類の数種動物飞於け
第 1 項 荃

1. 大腿骨

2. 下腿骨

3. 上跑骨

4. 前枷学

第 2 項 㧗 樣 蛙 第 3 節爬虫類

第 1 項 串

1. 大腿骨

2. 下腿骨

2. 上腕骨

4. 前枷角骨

第口項守宮

1. 大腿骨

2. 下腿骨

3. 上腕骨

4. 前䛷骨

第 4 章 考按並飞総括

1. 栄養孔

2. 栄巍血管

3. 骨艏内血管の分枝及び走行

4. 動脉, 静脉の関係

5. 鳥類, 車棲類, 爬虫類に汃ける 特巽的所見

第 5 章 結論

る長管骨々髄血管構造を娭索し多くの興味あ る所見を得たので報告する。

哺乳類以外の動物を用いて其の骨髄血管構 造の研究を行つた者を挙げれば，鳥類を用 いた者价 Denys ${ }^{13)}$, Bizzozero"9), Stricht ${ }^{(9)}$, 
Lengemann ${ }^{31)}$, Muir ${ }^{38)}$, Brinkerhof $f$ Tyzzer ${ }^{301}$, Helly ${ }^{2 \cdot 4}$, Dantschakof $f^{12)}$, Venzlaff ${ }^{(11)}, \operatorname{Doan}^{14)}$,

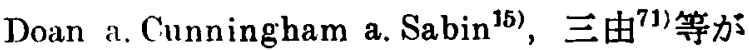
あり，雨棲類を用いた者飞 Rustizky (5)， Geelmuyden ${ }^{21)}$, Jordan a. Baker ${ }^{26)}$, 三由, 伊藤汹等がある，更に爬虫類を用いた者は家 聞にして予の涉猟せる範囲では教室三由の蜥 蜴及び蝼螈に関する研究があるのみである. 而して多くは細部血管構造に関する研究にし て主幹血管に関するすのは比較的少い。

予は本編に於て上記動物の長管骨々跹の主 幹血管系に就々て記し，あわせて哺乳類特に 家秉に於ける所見と比較検討を試みた。

\section{第2章实験方法}

1. 研究材料
鳥 類
鳩，鶏，雀，脊黄青㓦鵸
両棲類
摹, 殿様蛙
彴虫類
亀, 守宮

2. 研究方法

第 1 編に詳述せるスパルテホルツ式透明標 本, Resin 注入法, クッタペルカ注入法を用 いたが，主として用いたのはスパルテホルツ 式透明標本である。

而して観察は第 1 編同様として行つた。

\section{第了章 自家所見}

\section{第 1 節 鳥 類 \\ 第 1 項 鳩}

1. 大腿骨

\section{1）骨体部}

主栄羡孔は骨体内側後面略々中部に於て 骨壁を垂值又は僅が近位より遠位飞向け斜 飞貫くが，数例飞於ては動，静永が別々の栄 㪈孔を通り骨髄内と進入しているのが認めら れた．前者の場合では動脉が静脉の上位又は 並んで栄湌孔を通り，後者の場合では動脉栄 養孔が静脉栄養孔より近位に存することが多 く，耐栄養孔の距離は数 $\mathrm{mm}$ である。

栄盖動脉は骨髄内進入後直ちに上行，下行 の 2 大枝飞分岐し，各枝は夫々 $4 \sim 5$ 回の分 岐を行いつ小骨端に局 5 は家鬼に於けると同
様である，又平行動脉枝が認められるが家鬼 と異り主栄養孔が骨体の中央部にある為上行 枝，下行枝共略々同様な走行を示す．但し上 行枝は分岐直後盤くの間蛇行を示すことがあ る. 又動脉枝間の吻合は家兔飞於けるよりる 多く認められる。

栄羡静脉 動脉同㥞上行, 下行の 2 大枝汇 分れ軽度の迁曲を示しつ」走行し失々近位, 遠位端飞向 5 .

即ち上行主幹静脉洞は骨髄のや小後面寄り を走り，下行主幹静脉洞はや」前面寄りを走 行する. 上行主幹静脉洞は大腿骨頭後面より 進入するメ夕静脉と移行連絡する. 又下行主 幹静脉洞は遠位端のメ夕静脉と連絡するが㮰 位近くにてっ分する例がある。

主幹静脉洞の直径は骨䯣内径の約 140 1/15 を示し走行途中るとの太さは余り変らない.

又集合洞良く発達し，家鬼と同しく主幹 静脉洞に対し垂直又は栄養孔の存する側飞軽 く傾斜して集注する，尚軘脉が静脉を䌂絡す る状態は見られない。

口) 骨端部

近位メ夕動脉は主として後面より多数進入 する．家兔に於けるよりる長く且太いのが進 入し，骨髄内を骨体の約 1/8 の距離を分岐し つ〉走行するすのがある。これは後面内側よ り入るすのに見られ，他の部位より入るるの は編小なる動脉である。

而して静脉と同伴して進入する場合と然ら ざる場合とあること，及び骨髄内でその一部 は骨体部動脉の分枝と吻合することは家鬼に 於けると同様である。

メ夕静水は上記の如く後面より進入の大な るメ夕静脉ありて上行主幹静㲻洞と連絡する。 他飞細小なるメ夕静怺が少数大腿骨頭直下部 より進入する。

次にエピ動，静脉も主として大腿骨頭部の 後面にて種々の方向より進入する。

遠位端メ夕部には上記のメ夕静脉以外は細 小なるすのつみにて，主として後面より少数 の動，静脉が進入する。

エピ部にては家鬼と同しく主として後面の 
两顆間简より動，静脉が進入している.エピ 部骨能内にて動将枝間の吻合ある事，静脉も 主幹を以て吻合連絡することは家要に於ける と同様である。

2. 下腿骨
鳩の下腿骨飞於ては腓骨は脛骨の約 162 の 長さを行し，近位端のみ遊離するも殆んど全 長飞互り軟骨を以て脛骨に瘾合し骨髄の発育 は不良である。

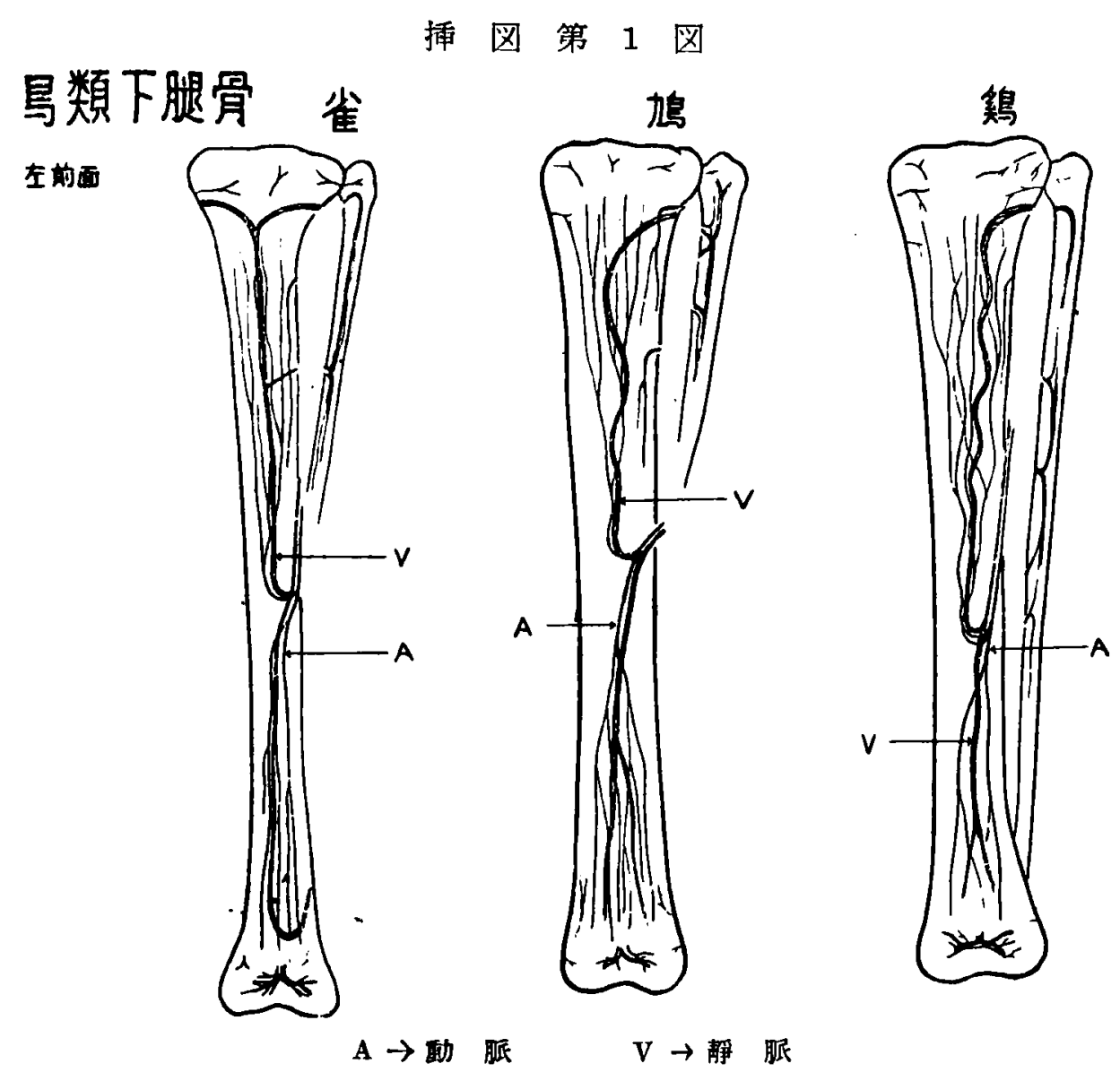

1) 脛 骨

(i) 骨体部

主采养孔は骨体の略々中兴外側にて骨壁を 近位より遠位に向け斜に貫き，動脉は静脉の 上位にて骨髄内に進入する。

野脉の骨䯣進入後の走行は略々家香に於け ると同様であり平行動脉枝の様相を呈する.

静脉は動脉の下位にて進入し同様に上行, 下行の 2 大枝飞分岐し, 上行主幹静脉洞は骨 螑の略々中头を軽度の迁曲を示しつ」上行し， 近位メ夕部後面より進入のメ夕静脉之連絡吻 合する. 又下行主幹静脉洞は骨涟の中火部を 走り，走行の任の距離より $2 \sim 3$ 枝に分岐 し遠位メ夕部後面のメ夕静永と連絡する。集 合洞恃上行枝, 特にメ夕部に於て良く発達し ている。 (ii) 骨端部

近位メ夕部では外側より太き $2 \sim 3$ 本のメ 夕動脉の進入があり，整く邈位へ走りたる後 骨体部動脉の分枝と吻合する，其の他細小な る動脉は多数進入する．静脉は上記の太きメ 夕静脉のある他, 細い静脉が少数後面より進 入している。

近位エピに於ても大なる動脉と静脉は外側 後面より進入する，他の部位からも細小なる 跣，静脉が少数進入する。

遠位メ夕動脉は主として後面より多数進入 し，静脉は上記メ夕静脉の他は細小である。 遠位エピに於て最大なる動, 静脉は後面よ り進入する，其の他, 側面及び前面からも細 小なる動, 静脉が進入している.

下腿骨飞於ても家鬼飞於けるよりる近位， 


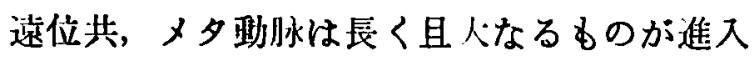
している.

口) 腓 骨

主栄養孔は骨体の略々中头内側, 即ち脛骨

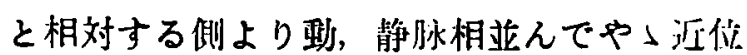

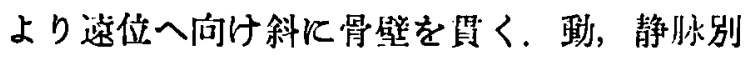
々の栄養孔を通り進入する例もある。

骨髄内にては動, 静脉共上行, 下行枝飞分 れて走行するが下行枝は甚だ芧弱である。

近位メ夕部では内側より進入するメ夕動, 静脉があり, 又エピ動, 静脉す内側或は後面 より少数進入する，䞗位端に於けるメ夕，工 ピ部怔, 静脉は認められない。

3. 上腕骨

鳩の上腕骨は特有な構造を呈する．即ち生 活環境飞適応する為骨体内は中空状態となり 骨髄は殆んど認められず，僅に骨端部に於て 多数に存する骨梁に沿い走る血管と，骨端部 及び骨髄内壁に於て所々飞存する静脉洞を認 めるのみである.

1）骨体部

主栄養孔は背面にて骨体の略々中央にて骨 壁を垂直又は近位より遠位に僅かに傾斜して
頃き，静脉上位又は理，静脉並んで進入する。

動脉は骨髄進入後直ちに上行, 下行の-2 大 枝飞分れ，上行枝は又直ちに $2 \sim 3$ 本に分岐 乙，静脉と共江骨髄队を斜飞対側飞向けて走 る骨梁に沿い，束状となりて走行し途中分岐 を行いつ」上腕骨の外側腹面の骨内壁飞至り， 外側腹面を分枝を增しつ」近位端に向い走行 する.

又下行動脉枝同様 $2-3$ 本飞分岐し，内 側脊面の骨髄内壁を这位に向け束状となりて 走り乍ら分岐を行い，下約 $1 / 4$ の部位に存す る骨梁飞沿い骨内の四方へ向け走行し，骨壁 飞至るや多数の分岐を行い各枝は夫々内壁に 淮小邀位端飞向 5 .

動脉は略々直線的に走るが，骨㵦内壁は所 々と維壁ある為その部を通過の際は動脉は屈 曲又は宿入する，又動永枝間の吻合は殆んど 認められない。

静脉は太き動脉とは同伴して走行するる細 小なる動永枝とは同伴せずして独自の走行を 示し，骨内壁飞て地図状飞拡る静脉洞飞移行 する。

而して骨体の上 $1 / 4$ 及び下 $1 / 4$ の部位より骨

挿図第 2 図

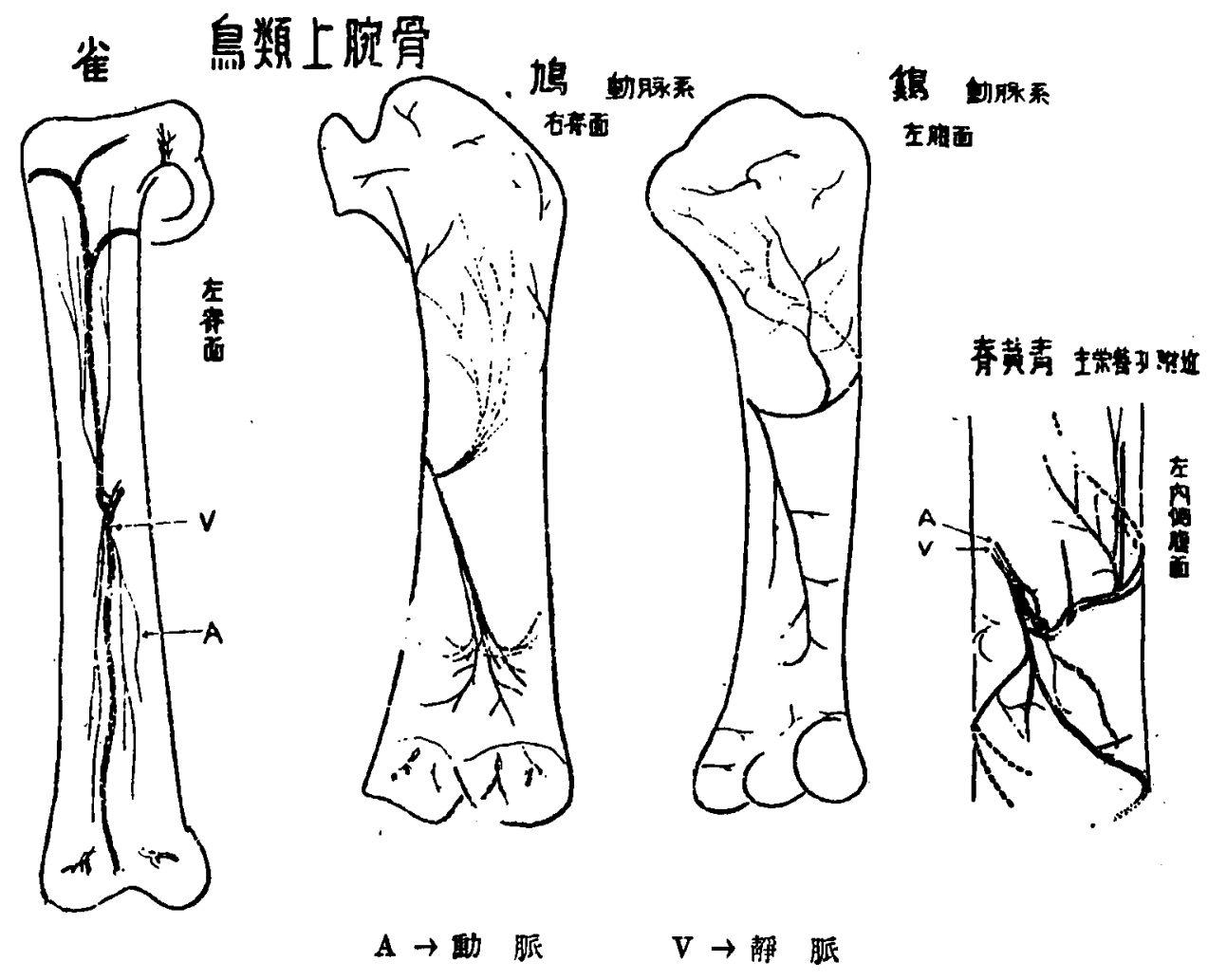


端部間は骨梁が多数存在し，此の骨梁に沿い 分岐せる動，静脉が骨内の㮔々の方问へ多数 走行する.

\section{口）骨端部}

上腕骨に於でメタ，エピの区別は著明で ない.メ夕動, 静脉に相当する血管は主とし て骨端部の脊面及び腹面より入り，丸い動脉 は多くは静脉と共に進入するが細小なる動, 静脉は別ヶの栄養孔を通り進入する事が多い， 而して進入後の動脉の分岐及び吻合あるは他 の骨に於けると同様である，又太き静脉は存 在せぬ様である。

\section{4. 前腕骨}

1）尺骨

主栄養孔は骨体の略々中头部，内側前面に
て骨壁を重直又は僅かに斜めに上方より下方 へ向け買き，静脉が上位飞て進入する。

.動脉は進入後直ち飞上行, 下行の 2 大枝に分 れ，時には既に孔内にて 2 分して居る例もあ る. 両枝洪平行動脉枝の様相を呈し，又動脉 枝間の吻合を多数に示しつ」夫々骨端に向い 走る。

静永も上，下行枝共骨髄の略々中头を軽度 の迁曲を示しつ〉走行し, 上行枝は近位メ夕 部にてメ夕静脉飞移行連絡する．又下行枝は 遠位端近くにて2 - 3 分枝に分れ内側より進 入のメ夕静脉と連絡する.

骨端部では近位，遠位其メ夕動脉は主とし て内側及び橈骨側より多数進入する，又静脉 は上述のメ夕静怺が近位及び遠位の内側ょり

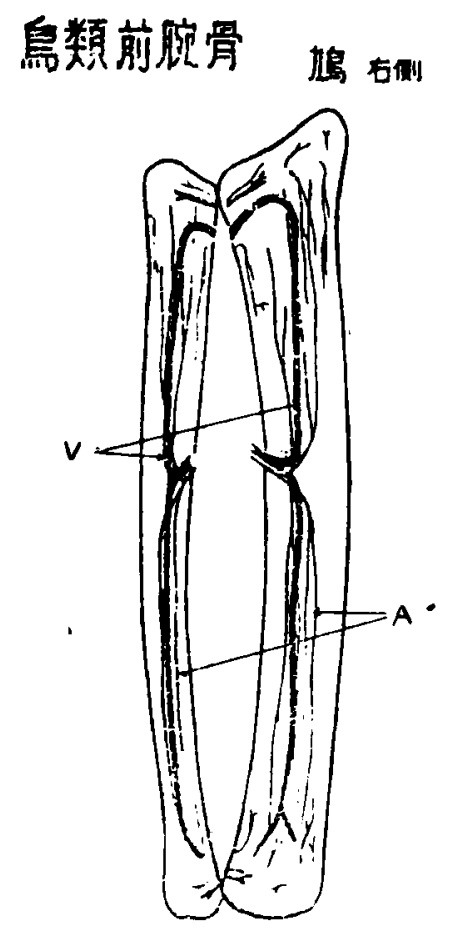

㧌図第 3 図

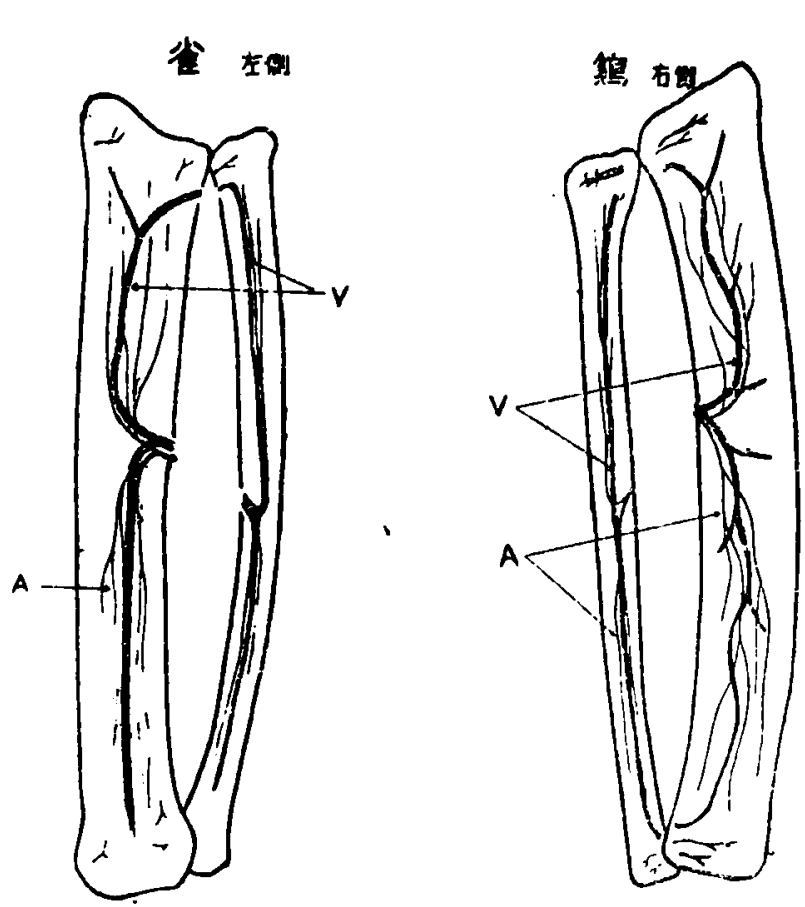

$\mathbf{A} \rightarrow$ 的脈 $\mathrm{V} \rightarrow$ 靜 脈

進入している，但じ遠位メ夕静脉は紐小であ る。

尺骨に於てもメ夕動脉は長大であり太い枝 を以て骨体部の動脉枝と吻合する。

エピ部に於いてもメ夕部同様内側及び前面 より動, 静脉が進入し，遠位端に於いては外 側からす太き血管の進入を見る.

口) 橈 骨
主栄養孔は骨体中央部内側後面, 即ち尺骨 の栄養孔と同じ高さにて相対する側に存し， 骨壁を垂直又は僅かに近位より遠位に斜に貫 き静脉上位㹸て進入する。

骨䯣内に於ける動, 静脉の走行は尺骨飞於 けると略々同様にして平行動脉枝を呈し，橈 骨飞於ては特に動脉枝間の吻合著明である.

上行主幹静脉洞は近位メ夕部内側後面より 
進入のメ夕静永と連絡吻合する。

骨端部に於けるメ夕，エピ䃼，静脉も主と して内側及び後面より多数進入する，沂位义 夕部前面からも辰大なる䋇脉の入る例があり， 当骨に於いてもメ夕動水は長大である.

\section{第 2 項 觅}

1. 大腿骨

主栄養孔は略々骨体川，部後面队側に存し 䢟位より近位に向け斜飞骨壁を貫き，静永は 動脉の上位又は相並んで骨髄飞進入する。 1 例飞於いては近位上り造位に向け進入してい た. 動脉の焦入後の走行, 分岐等は䳆飞於け ると格々同様である，但し動永枝は蛇行，迁 曲を示し平行動永枝の様相は示さない，又動 脉枝間の呀合は稀に䛱められる。

静脉同㥞上行，下行の 2 大枝飞分れ上行 枝は軽度の迁曲を示しつ」骨䯠後面等りを上 昇し，近位メ夕部内側より進入するメ夕静怺 飞移行連絡する.下行枝は略々骨䯣の中心を 整く走行後 2 分し，骨髄の内，外側を夫々這 位に向い走り，内側に存するメ夕静脉と連絡
する，集合洞は割合良く発達して抢り，主幹 静脉洞の太さは骨髄内径の約 1/8〜1,90である。 骨端部では近位メ夕部に上記メ夕静脉の進 入する事，メタ，エピ部に多くの細き血管の 進入ある事等は諙と略々同様である，又遠位 のメタ，エピ部の所見る大体䳆に類似する.

2. 下腿骨

楻に於ては遠位にて腓骨は軟骨を以て脛骨 と傯合するす家鬼の如く下 1, 2 の痹着は無く， 又骨髄も全く分離している。

1) 脛 骨

主栄養孔は骨体外側の上1/8の部にて骨壁 を近位より嗃位に向け斜飞垻き，骨長軸との 角度甚だ鋭角的である。動脉は静脉の下位 そて進入する。

骨髄内進入後の動脉の走行は鳩に類似する. 但し下项は骨髄の発育不良なる為分枝の数 も少数である，又動永枝は蛇行を示し，樹枝 状の分岐を行い平行動脉枝の様相は示さな W.

次飞静脉る上行枝は骨髄の略々中央を軽度

\section{鳥類大腿骨}

镍 左朔面
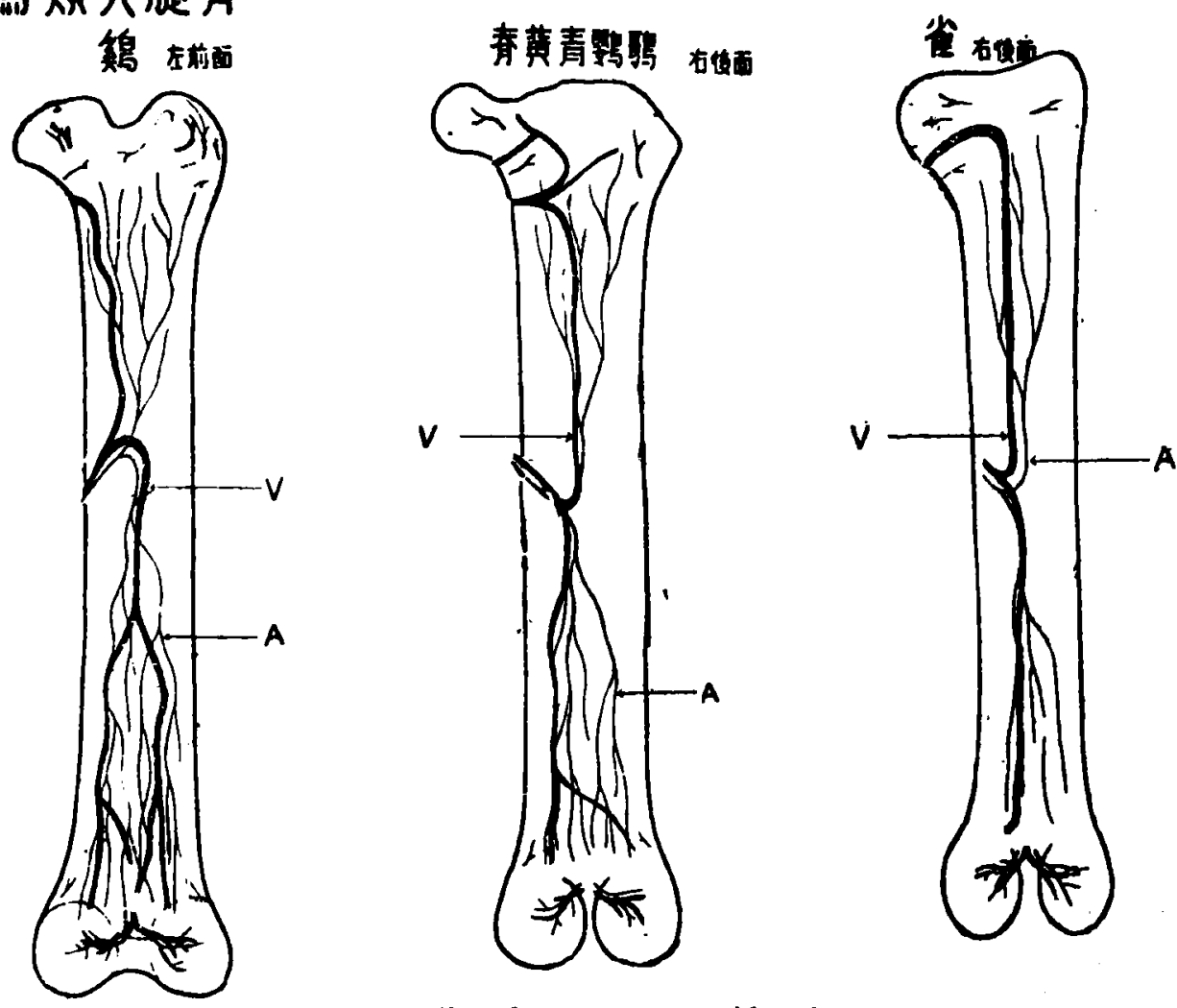

$$
\mathrm{A} \rightarrow \text { 䣦 眽 } \mathrm{V} \rightarrow \text { 静 脈 }
$$


の蛇行を示しつ」上行し, 近位メ夕部外側よ ク入るメ夕静脉に移行連絡する。下行枝は骨 能のや小外側奇りを走り逶位们向5，上行枝 は下行枝に比し太く，集合洞的良く発達して いる

骨端部では近位端飞上記メタ静脉の進入あ る他, 外側とてメ夕静脉孔と主栄養孔の略々 中間より垂直又は近位より週位に向け斜飞進 入するや」太き動, 静饯ありて, 骨奮内にて 骨体部の動，静脉枝と連絡吻合するが之は家 鬼飞於ては認められない，其の他メ夕、エピ 部共主として後面外側より多くの細小動, 静 脉の進入をみる。

遠位端メ夕，エピ部は䏨と略々同様にして， メ夕動脉は家鬼《於けるょりあ長大である.

口) 腓 骨

鴊腓骨飞ては動, 静永共別個の栄養孔を布

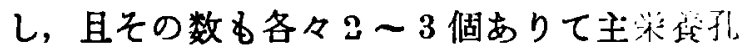
は不明である、之等策羬孔は内側化て近位よ り遠位へ向け又は逆方向に䑁壁を貫き，その 各々より野永或は静永が進入し，骨榷内にて 動, 静脉共夫々連絡吻合する。

近位骨端メ夕部内側飞や」大なるメ夕静脉 がある他はメ夕，エピ部共細小なる動, 静脉 が少数進入する，寀位メ夕，エピ部の血管は 著明でない。

\section{3. 上腕骨}

鶴飞於ても鳩と同様上腕骨は中空となり， 僅かに骨端部及び骨髄内壁飞静脉洞を認める のみである.

主栄養孔は骨体略々中块内側飞存し，近位 より邀位に向け斜に骨壁を貫き静脉が上位に て進入する。

動脉は進入後 2 枝飞分れ，上行枝は肯髄人 の腹側を横走し後近位飞向け屈曲し分岐を行 いつ」上昇する，又下行枝は骨壁腹面を走り， 雨枝共途中骨内壁飞沐 5 分枝, 及び骨梁飞泞 い骨醚内を斜に走る分枝を出すは鳩と同様で ある。

静脉は太い動脉とは同伴して走行する。， 細動脉枝とは必しも同伴せずして別個の走行 を行5.
骨端部メ夕，エピ部の境界は明碓でなく， 近位メ夕部内側腹面飞や」大なる 1 個のメ夕 静脉ある他, 主として腹面より細小なる動, 静脉が多数進入する。文遠位化於てる主とし て内側及び腹面より細小なる動，静脉が進入 する.

4. 前涴胃

\section{1）尺 骨}

主栄羡孔は骨体内側飞て中块よりや」上方 にて近位より薏位に向け斜飞胃壁を貫き静脉 が上位にて進入する.

動永の骨髄進入後の走行は鳵と同様なるも 蛇行を示し平行動脉枝の様相は認められない。 静脉も㴧に於けると略々同様の走行を示する や〉蛇行が著明である。

骨端部では近位, 景位共メ夕部内側よりや 」太きメ夕静脉の進入ある他少数の動脉の進 入があり，近位，遠位エピ部共細小なる動， 静水の進入あるも鳩と略々同様である.

口）橈 骨

主栄養孔は骨体の略々中头の内側後面飞於 て尺骨の主栄養孔よりや」遠位に存し, 進入 型式は尺骨に類似している。例に依つては動 脉のみ進入し静脉進入の認められ例すあ る.

骨髄内進入後の動，静脉の走行は略々尺骨 に於けると同様である。

骨端部では近位, 遠位内側にや小大なる 夕静脉の進入ある他, メ夕，エピ部共主とし て内側より細小なる動, 静旅が少数進入して いる.

\section{第3 項 雀}

1. 大腿骨

主栄養孔は骨体略々中兴飞て後面又は内侧 後面に存し骨壁を垂直又は近位より遂位へ问 け斜飞貫き，静脉上位或は動，静脉並行して 骨髄内飞進入する。

動永の進入後の走行は鸠大腿骨飞於けると 略々同様であるが平行動脉枝は定型的でない，

静脉も上行, 下行の両枝共迁曲を示しつ」 略々骨髄の中央を走り，上行枝は近位み夕部 後面より入るメ夕静脉と移行連絡し，下行枝 
は骨端に至りミ〜3 分しとの 1 つは脛側上顆

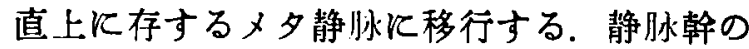
太さは最大骨骮内径の1/反を示す例があり， 集合洞は割合良く発達している，其の他は㴧 飞於ける所見と類似する.

骨端部近位メ夕部に上記メ夕静脉ある他， 細小なる動脉が少数進入するが鸠に於いて認 められた長大なるメ夕動脉は見られない，工 ピ部では大腿骨頭の後面より1〜 こ対の細小 なる動，静脉の進入あるのみである。

遠位にても上記メ夕静脉ある他は殆んぞ動, 静脉共認められない。エピ部は鳩大腿骨飞於 けると略々同様である。

\section{2. 下腿骨}

鳩と同様腓骨は発自不良にして脛骨の約 厸飞過ぎず，近位端は遊離するも遠位にては 軟骨を以て脛骨と瘾合する。

\section{1) 䐤 骨}

主栄養孔は骨体の略々中头又はや小遠位奇 りの外側にありて，近位より造位に向け骨軸 そ対し甚だ鋭角的飞骨壁を貫き，静脉上位或 は動, 静脉並行して骨髄内に入る。

骨髄内進入後の動脉は大体鳩の脛骨飞於け ると同様にして上行, 下行動脉枝共平行動脉 枝の様相を示す。

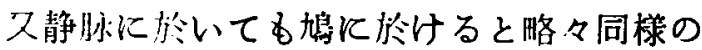

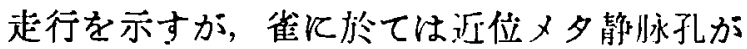
外側に存する例と内側飞存する例とあり，少 数例飞於いては内，外画側儿存寸るものもあ る. 又遙位メ夕静脉は後面外側上り進入して いる.

次に 2 - 3 位に於て江倍外側メ夕静脉孔と

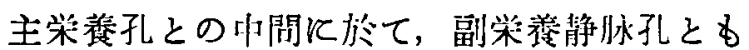
云うべき栄羡孔ありて静脉のみが通過し，骨 髉内飞進入後上行主幹静脉洞と吻合している のを認めた。

骨端部证位メ夕部の内，外側よりや」太き 動脉が 1 本宛進入する例多く，他の部位から る細小なる 1 〜本の動脉が進入する，静脉 は上記メ夕静脉の他は著明なるものは認めな い. 近位エピ部にては外側及び後面より数対 の動, 静脉が進入する。
遠位メ夕部には上記メ夕静脉の他, 少数の 細小動，静脉が主として後面より進入する. エピ部は鳩と略々同様である。

口)’腓 骨

主栄養孔は骨体の略々中央内側飞て近位上 り薏位に向け僅かに斜飞骨壁を貫き動，静脉 並んで骨髄内に進入する。

進入後の動, 静永の走行は鳩と略々類似寸 る.

近位メ夕部には 1 個のメ夕静脉の進入ある も動脉の存在は不明である。 又エピ部にてる 内側より 1 対の野, 静脉が進入する.

遗位メ夕，エピ部の血管は認めない。

\section{3. 上腕骨}

雀飞於ては䲴と異り上腕骨飞於ても骨髄は 割合良く発達している。

主栄養孔は骨体中央部飞て背面に存し，骨 壁を䜣位より徒位に向け斜飞貫き，動脉が上 位にて進入するが1例に於ては野涾が下位飞 存するのを認めた。

動脉は骨煘迶内進入後上行, 下行の 2 大枝に 分れ，整く走行の後分岐を行いや」平行野脉 枝の様相を呈する。

静脉も同粎上行，下行の.大枝飞分れるが, 上行枝は骨野道の略々中尖を走り近位端内側飞 てメ夕静水と連絡するが，例飞依つては外側 にもメ夕静怺の入るものるある。下行枝も骨 䯣内の略々中心を走り寀位メ夕部にて腹面の 画顆間䉥部に存するメ夕静脉と連絡吻合す る. 主幹静䏡洞はや」迁幼した走行を示し, 集合洞は制合良く発達している。

主幹静㕫洞の太さ惊行途中余り変らず, 且最大は骨骮得内約 1/6亿達する。

近位骨端部には，上記入夕静脉の進入ある他， 少数のメ夕動脉が脊面より入るのを認める.

エピ部にては内側に 1 対の動, 静脉の進入 ある他は血管は認めない.

遠位メ夕部にても上記静脉の進入ある他, 動脉の細小なるものが 1 2 2 本腹面より進入 する：エピ部に於ては少数例のみ腹面より進 入する細小なる血管を見る。

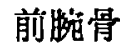


-1)尺骨

主栄養孔は骨体略々中火部にて橈骨との対 側飞存し，骨壁を垂直又は僅かに㟫位より近 位へ向け貫き，怔，静脉並行して又は静永上 位飞て進入する 1 例に於ては動脉, 静脉の 栄秦孔が別々にして，静脉栄養孔が動脉のそ れより近位にある例を認めた。

骨䯣内進入後の動，静脉の走行は九鳥尺骨に 於けると略々同㥞なる゙す平行動永枝は九鳥飞比 し不完全であり，静脉り上行枝は略々骨髄の 中心を走り近位メ夕部内側飞存するメ夕静脉 と連絡吻合する。1 1 例飞於てはこのメ夕静脉 の他飞外側飞る〉細きメ夕静怺の存在する のが認められた。 下行主幹静脉洞る略々骨䯣 の中央を走るが末端の分岐仗想められず，2 〜 3 例飞於てのみ 2 枝になつているのを認め ז.

骨端部は上記近位メ夕静将の他はメ夕，エ ピ部共血管の進入は少く，内側より細小なる あのが少数進入するのを見るのみである 又 遠位飞於ける太きメ夕静脉の進入は無く， 1 例飞於てのみ紐きメ夕静脉の進入が見られ た.

口) 橈 骨

主栄養孔は骨体中头上りや」遠位にて尺骨 と相対し，近位より寀位に向け斜飞骨壁を貫 き動，静脉並んで又は静脉上位にて進入し， 鳩に於けると略々同様の走行を示す。但し上 行, 下行動永枝共飞 1〜2本の分岐を示すの みで静脉は分岐を示さない。

一骨端部では䚾位メ夕部外側飞於て細き静脉 が入り上行静脉洞と遇絡吻合する他は記すへ き血管の進入は認められない。

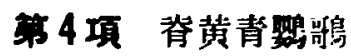

略々雀に類似せる所見を呈するがその異れ る点のみを記述する。

1. 大腿骨

主栄羡孔情体の略々中炔内側後面飞存す る。但し雀と異り動，静脉が1つの栄葲孔よ ク入る事は少く，多くの例で動，静脉は別 々の栄養孔より骨髄内飞進入する。この堦合 画栄養孔の距離は $0.5 \mathrm{~cm}$ 以内であり, 静阥
栄食孔が近位笴りにあることが多い，静脉栄 養孔は垂直又は僅か斜に近位より裳位へ向け 骨壁を貫き，動脉栄養孔はや小遠位より近位 へ向け斜賁くのが多い。

骨髄内進入後野脉は上行, 下行枝共㫌くは 蛇行を示し，間子無く直線的となり分岐しつ 小骨端に问 5 が定型的の平行動脉枝の様相は 示さず，又動脉枝間の吻合子少い。

静脉の上行枝は骨䯣中央を走り近位メ夕部 後面内側奇りから入るメ夕静脉と連絡する。 又下行枝は後面に偏して走り遠位端近くにて 2〜 3 分し, 後面の両顆間窝より入るメ夕静 脉と連絡する．静脉幹の太さは骨随直径の約 1/10であり，其の他は往に於けると同様であ る.

䜣位骨端部にては上記メ夕静脉の他, 少数 のメ夕動脉が主として内側及び後面より進入 する．又エピ部於ては大腿骨頭直下部及び 後面より 1〜2本の野，静永が進入する.

遠位メ夕部では前述のメ夕静脉の他に，少 数の゚メ夕動脉が後面及び内，外側より進入す る. 又エピ部は雀に於けると略々同様である。

2. ‘下腿骨

雀と同様腓骨は発育不良にして脛骨の約 的にして軟骨を以て脛骨と瘾合する。

1) 脛 骨

主栄養孔は骨体中央よりや」近位の外側飞 存し，進入様式は往と同様である。

骨髄内の動脉の走行は隹に於けると略々同 様沉てや」平行動脉枝の様相を呈する，静㲻 は上行，下行枝共迁曲を示しつ」走行し，上 行枝は近位メ夕部では外側近くを走り外側よ り進入のメ夕静脉と連絡吻合する．下行枝の 走行は街に於けると同様である。

近位骨端部には上記メ夕静脉の他飞雀と同 じくメ夕部の内，外側よりや」太い動脉が 1 本宛進大乙上行主幹野脉枝と吻合する，他飞 は主として後面及び外側より少数のメ夕動脉

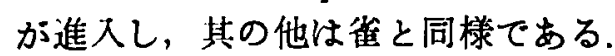

口) 腓 骨

著明なる血管の進入は無く，近位メ夕部よ り入る静脉，及びそれよりやょ下位飞て入る 
動永が主なるものである.

\section{3.上腕骨}

鳩の上腕骨と類似し，骨鹃は中空で静脉洞 の発育は甚だ不良である.

主栄養孔は骨体内側の略々中央部飞存し， 骨壁を僅かに斜めに迋位へ向け貫き，動脉が 上位又は動，静脉亚んで進入する。

動脉江進入後間 す 無く上行, 下行の a大枝 飞分れ，上行枝は骨内壁の腹面を斜め上方に 走り, 外側に至り分枝を多数出しつ」近位に 向う。下行枝はそのま」内側を走り下行し， 股面及び监面へ多くの分枝を出し骨壁内面飞 広く分布する．而して骨端部近くにて仼と同 様多くの発育せる骨梁を介して四方へ走行す る.

静脉も同様 2 大枝飞分れ，太い動脉と同伴 して走るが間る無く細枝を出し，動脉とは必 しも同伴せずして骨壁内面に地図状を示せる 静脉洞網炕終る。

骨端の近位メタ部にては脊面及び内側に数 本の細小なるメ夕動，静脉の進入を見，エピ 部にても主として背面より動，静脉が少数進 入している 祘位メ夕，エピ部にては主とし て腹面より数本の細小なる動，静脉が進入す る.

4. 前腕骨

\section{1）尺骨}

主栄養孔は篗に於けると同位置に存し，骨 壁を重直又は僅かに近位より遠位に向け斜に 貫き，動脉上位飞て進入する例が多い，又多 くの例ではそれよりや」遙位倸栄養孔ありて， こっには静脉のみ通過する。

動脉の進入後の走行は略々雀と同様にてや 小平行動脉枝の様相を呈する。静脉子往《略 々類似して居り，少数例では近位の内，外阿 側にメタ静脉の入るるのがある，下行主幹静 永洞は副栄養静脉孔より入る静脉と吻合して 遠位飞走り，遠位メ夕部にて内側前面上り入 るメ夕静脉と連絡する。

近位骨端部は雀と同様である。㟫位にては 上記メ夕静脉の他, メ夕，エピ部共, 内側及 び前面より少数の組い血管の進入を認める.

\section{口）橈 骨}

主栄養孔は骨体の内側後面略々中央飞存し， 野, 静脉並んで近位より遠位へ向け斜飞進入 する.

骨髄内飞於ける動，静脉の走行は雀飞於㚈。 ると同様にして，近位及び遠位の外側にメ夕 静脉孔を認む。

骨端部にても内側及び後面より少数の細小 なる血管がメタ，エピ部共に進入している。

\section{第 2 節 両 棲 類}

\section{芽 1 項 蟇}

\section{1. 大腿骨}

幕に於ては栄養動, 静脉別々の栄養孔を有 し，1つの栄養孔より動, 静脉共に入る事は むしろ稀である，又個体差が甚しく進入の一 定様式は認められない，多くの例では動脉の 栄養孔は骨体の略々中头飞て内側後面飞存し， 骨壁を近位より逶位に向け斜めに貫く，静脉 の栄盖孔は同じく内側後面にて, 動脉栄養孔 の近位及び遠位寄りに夫ゃ 1 個宛存し，近位 端に近きすのは近位より遠位に向け，遠位端 に近きすのは垂直又は僅かに近位より遠位に 向け骨壁を貫いている.

動脉は骨髄内進入後上行, 下行の 2 大枝飞 分れ走行し, 途中多くの分枝を出すが平行動 脉枝の㥞相は示さず，分枝は蛇行旋回を示す。 分岐は骨端部近くに於て特に著しく認められ る.

静脉は夫々の栄養孔を介して進入し，骨髄 内に於て連絡吻合し上下：枝に分れて軽度の 迁曲を示しつ〉走行し，多くの集合洞を分岐 するが分岐方法は帚状である．主幹静怺洞の 太さは最大骨髄内径の約 190 K達する。

又動, 静脉は骨䯣内進入後, 暫くの間は相 其叱密接して走行する事が多いが程絡は示さ ない。

骨端部の近位メ夕血管は甚だ稀にのみ認め られ，動，静脉は個々別々に入る，エピ血管 は甚だ特異的な走行を示すが第 3 編飞群述す るを以て省略する，又近位の骨髄中央部より 骨頭内へ笑出せる血管網を認めるも之も後述。 


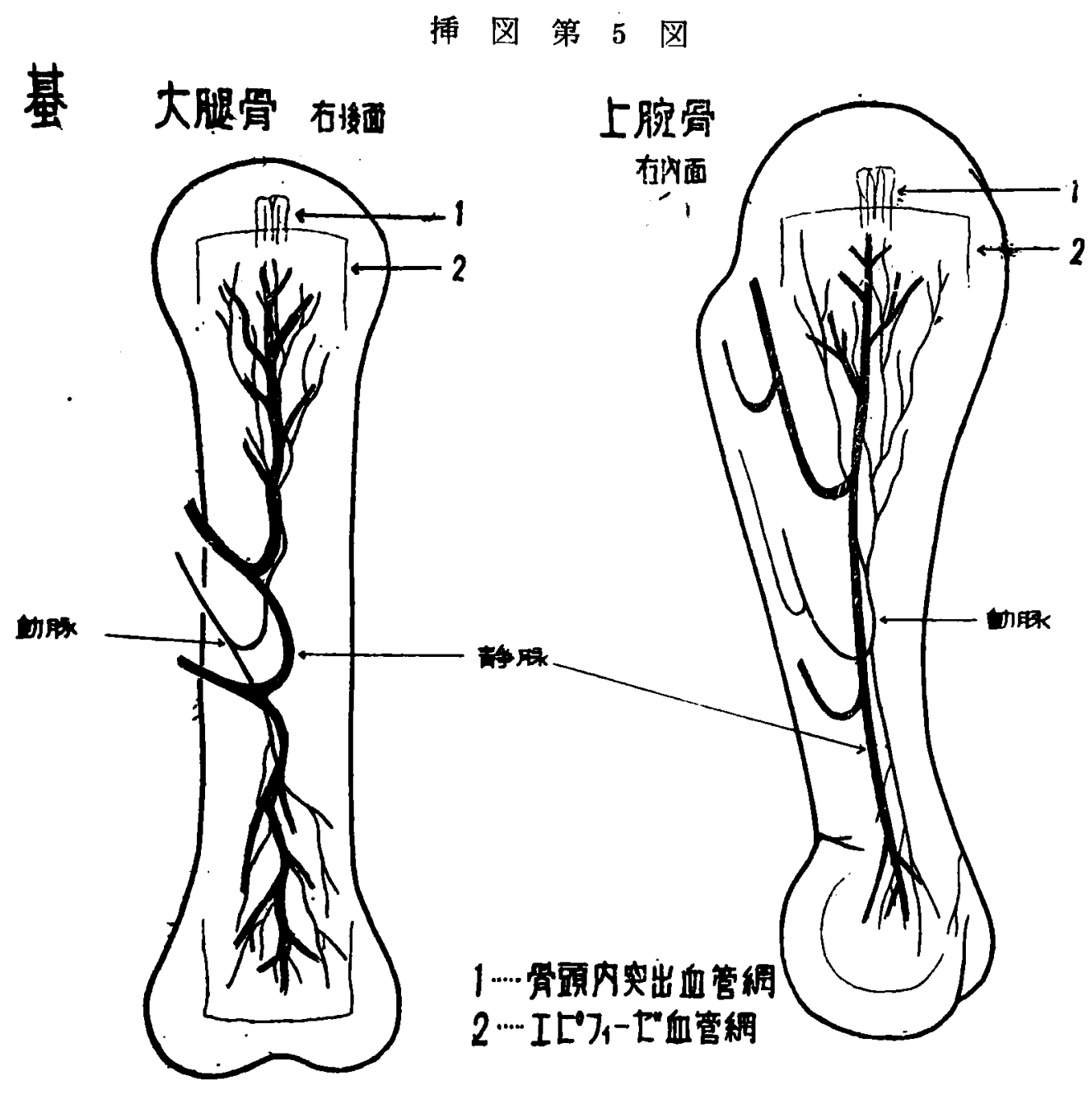

する.

遠位メ夕血管る稀にのみ認められ，エピ血 管の分布様式る近位に於けると同様である。

2. 下腿骨

下腿骨は脛骨，腓骨瘾合し骨体中央部では 骨髄も完全飞雨者共通となるる，骨端近くに ては両者の間に軟骨板が存在し両者の骨髄は 分離されている，故江脛と腓骨と区別せず 下腿骨として記述する。

一下腿骨にて特異なるは策盖動脉の進入方式 である。即ち骨体の略々中头飞て後面上方よ り前面下方へ向け骨体を貫く太き（骨䯣直径 の約 1/4）動脉ありて，之の骨髄内通過の際，

上行，下行の主幹動脉を分岐する。

主幹動脉は蛇行しつ〉各々2 本の分枝に分 れ，分枝す又蛇行を暫くの間示した後下腿骨 の内側及び外側飞分れ，樹枝状に細動脉枝を 多数分岐てつ小骨端部に至る。

次に静脉の栄養孔は多数あり，即ち骨体中
央部の内側飞て骨壁を種々の方向より貫く栄 養孔と，雨骨間飞軟骨の存する部にて後面中

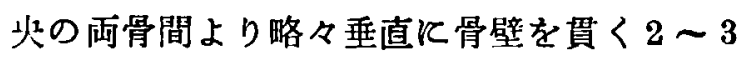
の静脉孔がある。

各々の栄養孔より進入せる静脉は骨髄内に て連絡吻合し，骨体中尖部では1本となり，

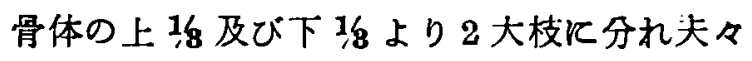
骨端部に至る。

近位, 琁位骨端部共, メ夕血管は稀飞のみ 存在し，エピ血管は大腿骨に於けると同様特 翼なる走行を示す。尚大腿骨近位に見られた 骨頭内突出血管網は存在しない。

\section{3. 上腕骨}

上腕骨に於ても栄養孔の位罩は一定せず, 多くの例では動脉は骨体の下 1/89前面又は 内側飞て，近位より遠位に向け骨壁を貫く栄 羡孔を介して骨髄内に入り上行, 下行の 2 大 枝に分れ夫々樹枝状に分枝を出しつ5骨端に 问い走る. 又その 1 分枝は骨体前面の突出せ 

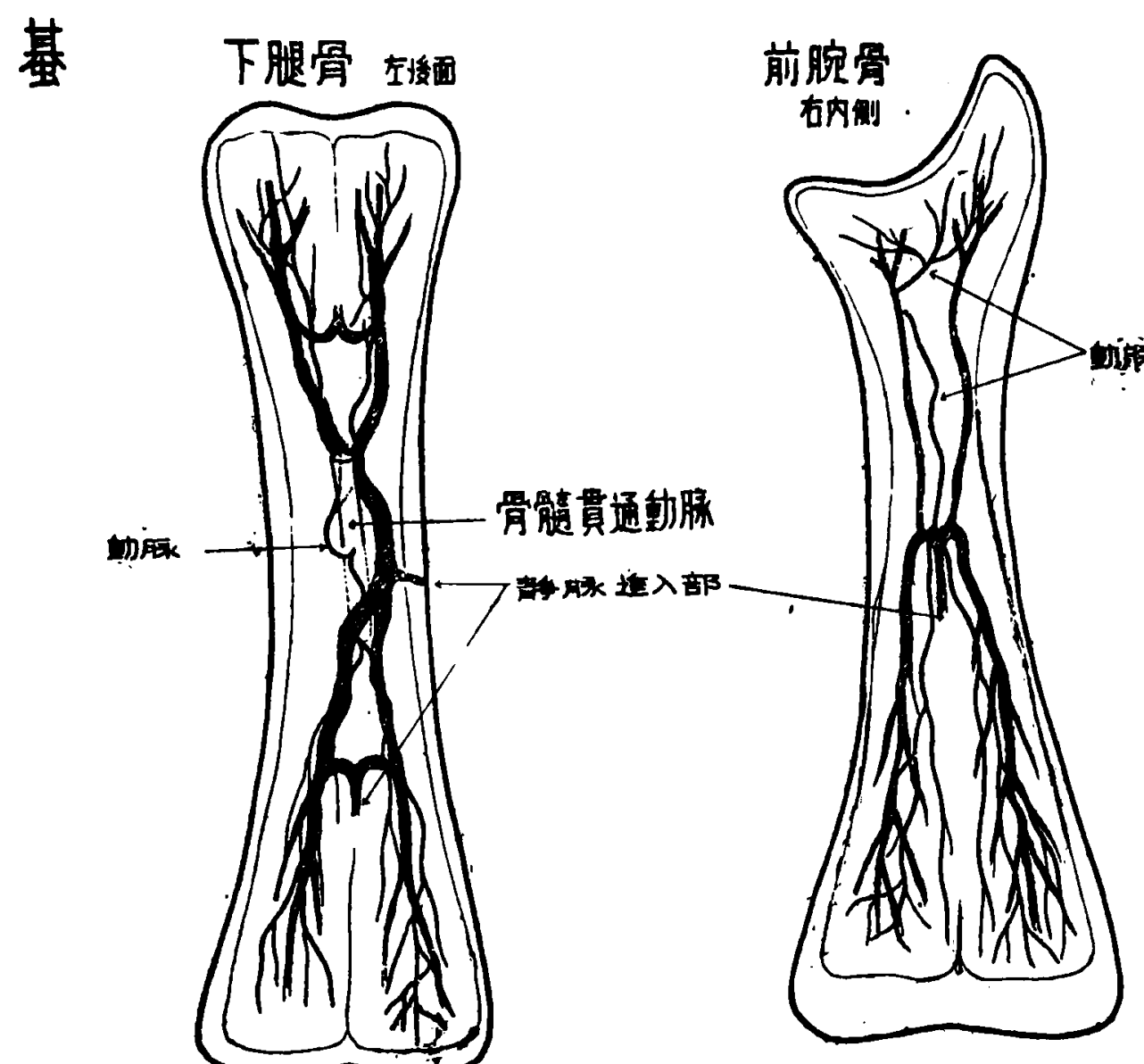

る骨内に存する分離せる骨髄に走行する。

基に於いても上行枝は下行枝飞比し走行距 離が長く，且動怺枝の太さす大である，又上 行枝は分岐多きに対し下行枝は分岐が少い。 尚上行枝は進入直後は蛇行を示す例が多い.

静脉は動永栄養孔より近位及び迹位の骨体 前面にて，夫々近位上り寀位に向け斜飞骨壁 を貫く静脉孔を通り，骨髄内で連絡吻合し骨 端飞向い走行する，吕も動脉と同じく上行枝 は良く分枝を出する，下行枝に於てはその数 が少い，又近位より進入する静脉からや」太 き 1 本の分枝が動脉同様，笑出分離せる骨髄 内纷分布する

近位骨端部メ夕血管は甚だ稀にして，エピ 血管は大腿骨飞於けると同様である。又近位 にて骨頭内笑出血管網が認められる，皠位に ては関節面近き部位にて，多くは前面及び後 面より個々の栄養孔を介して進入するや」太 きメ夕動, 静浆各々 $1 \sim 2$ 本ありて，骨邻迶内 にて骨体ょりの動，静永と夫々連絡吻合する，
遠位に於けるエピ血管は認められない。

4. 前腕骨

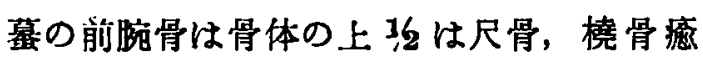

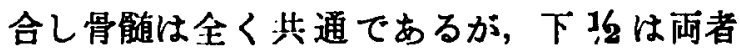
の間飞軟骨板が存し骨髄を 2 分する.

当骨飞てる血管進入方式は一定していない が，多くの例では懒脉は骨体内側中坐の近位 端近くにて，骨壁を邀位より近位に向け僅か 斜めに貫く栄養孔を介して骨髄内進入し， 直ちに上行，下行の 2 大枝飞分れる.

或る例では上行枝のみ別個の栄養孔より入 り，あたかるメ夕動脉の如き様相を示す場合 がある。

いずれの場合す上行枝は 2 枝に分れるが， 尺骨側飞至る動脉枝は㳳骨側の動脉枝より大 である.

下行枝は蛇行を示し乍ら間すなく2 分し， その分枝る又赖く蛇行を示した後尺骨，暁骨 倒飞分れ，夫々樹枝状飞分枝を出しつ小遠位 飞向い走行する。 
挿 図 第 7 図

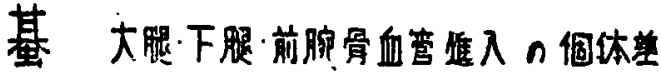
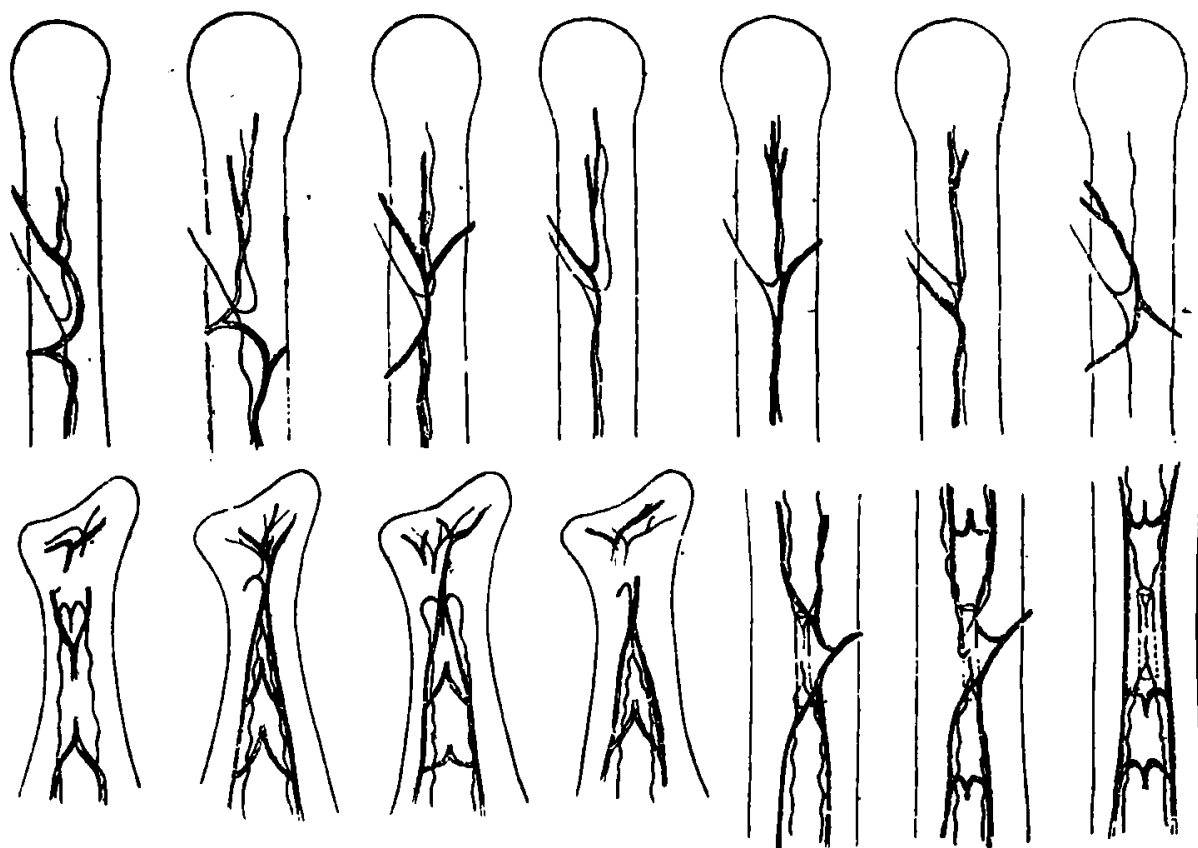

又大腿骨飞於け る栄養静脉孔が比 較的接近して居る ので三由の云う如 く, 恰も骨髄内を 静脉が横断してい るが如き観を呈す る例がある。

第3節爬虫類 第 1 項 亀

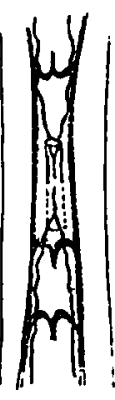

1. 大腿骨

大腿骨注強く前 方へ突攀し，大腿 骨頭も前方へ届曲 してその後面は陥 山している。

主栄養孔は骨体

静脉は上記動脉進入部附近及び骨体の下 16の内側，両骨間より近位から遠位任向け斜 飞骨壁を貫き進入する。骨䯣内に於て静䏘は 連絡吻合し，動脉と同じく骨体の下 16 は 大枝に分れ夫々骨端飞向 5 .

前腕骨飞於ては動, 静脉其飞上行枝に比し 下行枝は甚だ発育良好である.

近位骨端部にては少数のメ夕動，静䏡が骨 体の内側及び外側に於て別々の栄養孔を介し て進入し，骨髄内飞て骨体部動，静脉と連絡 吻合する，又エピ血管は認められない，邀位 そてはメ夕血管は甚だ稀であり，スエピ血管 は大腿骨に於けると同様の分布を示す。

幕飞於てはすべての骨飞於て平行動浆枝の 様相は認められない。

\section{茅2 项 殷様蛙}

大腿骨，下腿骨，上椸骨，前锘骨いずれる 蟇に似た所見を呈し，特に大腿骨に関しては 既に教室三由に依り発表されているので省略 する。

但し蟇㳊於いて認められた大腿骨，上肪骨 近位の骨頭内に突出せる血管網は認められず, 且エピ血管網の発有るすへての骨に於て蟇に 此し不良である。
の上将の後面に有りて，骨壁を寀位より近 位飞向け斜潧き骨軸との角度は $20^{\circ} \sim 30^{\circ}$ である，栄養血管は野，静脉並んで進入する が，少数例では動永のみ進入し，メ夕静脉が 栄養静脉の代役するが如き観を呈することが ある.

動水系は栄養孔通過の際既にコ〜 3 分し, 骨髄に入るや特:買なる走行を示す，即ち，骨 骮道内進入後直ちに細き動脉枝飞分岐し，家象 其の他飞於ける如く上行, 下行主幹動脉之名 付くべきすのは無く，細動脉枝間に多くの吻 合を示し粗なる網状を形成し，骨髄の中心を 走る静脉系の周囲を囲嬈するが如き観を呈し， 骨哩道の全長飞互り分布する，而してその栄養 孔附近に於ける動脉枝之骨端部附近の動脉枝 の太さには大差を認めない。

又特に亀では骨膜より進入する細動脉枝が 豐富に認められ骨髄内動脉網に吻合する。そ の為か主栄養孔に於ける野脉は甚だ細小であ る.

次飞静脉は進入後上行, 下行の 2 枝飞分れ るも分岐部より直ちに集合洞样のものに分枝 し，之は更に直ちに大きな静脉洞網となり， 之等静脉洞網は骨䯣の略々中心部を動脉網に 
㨉図第8 図

\section{守宮長管骨血管系 刍尺骨血管系}

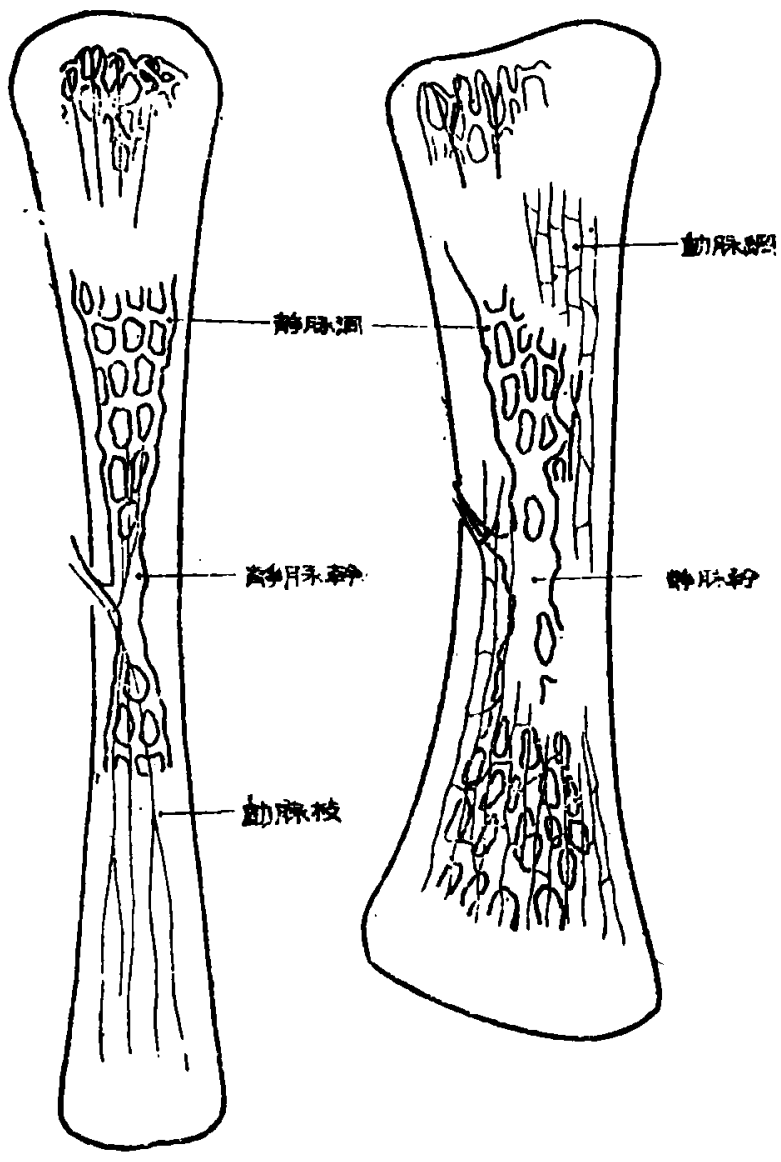

囲繞されつ」走行し，他の部位より入るメ夕 静脉と吻合連絡する，而して骨端部近くの静 脉洞網は進入部附近のに比しや」小である。

近位骨端部：後面宿部にや」大なるメ夕 静脉孔ありて，上行し来たれる静脉洞と連絡 吻合する，其の他後面に多くのメ夕動，静脉 ありて，夫々骨䯣内飞於て動脉又は静浆と連 絡吻合する．又大腿骨頭の後面にて進入する 数対の動，静水は骨骮有内を前方飞進み大腿骨 頭内に分布する.

遠位にても主として後面より多くのメ夕動, 静脉が進入し，特飞後面雨側飞や小大なる動 脉が進入する。

亀に於てはメタ、エピ部の境界は明かでな W.

\section{2. 下腿骨}

鼌の下腿骨は脛骨，腓骨は夫ァ全く分離し ている.

1) 脛 骨
主栄養孔は骨体後面中头よりや小遠位 に存し，骨壁を近位より遠位に向け貫く。 主栄養孔は 1 個の時が多いが，例飞依つ ては接近して 2 個, 時には 3 個存するこ とがある. 又趿, 静脉共化 1 孔より入る 例と，別々の栄養孔より入る事とがあ る. 後者では野脉が静脉より近位にて進 入する。

骨髄内に於ける動，静水の走行形式は 大腿骨と同様である。

骨端部飞於ては近位外側よりメ夕静脉 が進入し，其の他飞る小なるメ夕動，静 脉が個々飞骨髄内に進入する，又㟫位に ても主として外側よりメ夕動, 静脉が進 入する.

口) 腓 骨

主栄羡孔は脛骨の主栄養孔と相対する 位置にありて，脛骨と同じく近位より遠 位に向け骨壁を貫き動脉上位にて進入す るが，栄養孔数は例壮依り $2 \sim 3$ 個もあ ることがある。

骨髄内の走行は他の骨飞於けると同粎 である.

3. 上腕骨

主栄養孔は骨頭部内側に存し，近位より遠 位に向け斜飞骨壁を買き動，静永並んで進入 する. 少数の例では上記栄養孔よりや」造位 奇りの内側飞小なる栄養孔を有するものがあ つた.

骨娟内の動, 静脉の走行は大腿骨飞於ける と同様である。

近位骨端メ夕部内側より多くのメ夕血管の 進入があり，息位にても内側中尖及び腹面寄 りルメ夕静脉孔がある。その他の部よりる少 数のメ夕血管の進入を見る。

\section{4. 前腕骨}

1) 尺 骨

主栄养孔は骨体内側中尖よりや」遠位寄り そて，垂直又は近位より透位に向け斜に骨壁 を貫き動，静脉並んで進入する，少数例では 栄美孔が近接して 2 個ある例るあり，此の場 合には動脉が遙位飞ある事が多く，又静脉孔 
の2 個ある例すある.

骨髄内飞於ける野，静脉の走行は大腿骨に 於けると同椂である。

骨端部では近位，造位共，内側より多数の 練小血管が進入する。

口) 暁 骨

主栄養孔は内側にて尺骨に於けると略々同 位置に存し，骨壁を垂直又は近位より薏位へ 向け，或は其の逆方向に貫き野，静脉亚んで 進入するるの」如く，骨髄内に於ける走行は 上記の骨に同じである。

骨端部血管も内側腹面より細小なる血管が 進入する。

\section{苇2项 守 宮}

\section{1. 大腿骨}

主栄養孔は骨体後面中头よりや」近位寄り 飞存し，骨壁を遠位より近位へ斜めに貲き娅 脉上位, 又は動，静脉並んで進入する，数例 に於ては動，静脉別々の栄養孔を通るものも ある.

動脉は進入後上行, 下行の a 枝飞分れ, 夫 々少数の分岐を行いつ」骨端飞向 5 が平行動 脉枝の様相は定型的でない。

静脉子同様 2 分し夫々骨端化向 万が，骨体 の小なる為主幹静脉洞と称すべきのは無く， 又集合洞も無く，直ちに静脉洞に分岐し骨鲔 内を満たしている.

骨端部では大腿骨頭に相当する部の後面よ りや」大なるメ夕静脉の隻入むり，メ夕動脉 の進入は不明である。遠位にてる後面中央よ クメ夕静脉の進入あり，又メ夕動脉の進入る 1〜2本認められた. エピ部は近, 遠位共, 後面より少数の動，静水が進入している.

\section{2. 下腿骨}

\section{1) 脛 骨}

主栄羡孔は骨体外側略々中少飞て肖熋を僅 か斜めに景位より近位に向け頃き動，静脉並 んで進入するが，時には静脉のみが入り動标 注别個に内側より進入する例がある。

骨髄内の動, 静脉の走行は略々大腿骨飞於 けると同様にして平行動脉枝は認められな い.
骨端部の近位メ夕, エピ部では外側後面に て1〜 ロ本のメ夕動脉及び 1 本の静脉が入る. 又逴位メ夕部では1例のみにメ夕静脉らしき ものが外側より進入するを認めた. エピ部の 野, 静脉は後面にて少数, 細小なるものが入 る.

口）腓 骨

主栄養孔は内側飞て脛骨栄養孔よりや」遠 位にて，骨壁を垂直又は僅かに近位より遠位 そ问け貫き動，静脉同伴して進入する，例に 依りては動, 静脉別々の栄養孔を有し，静脉 が近位寄りで入るのもある。

骨髄内の走行は他の骨に略々同様である。

骨端部のメ夕は近, 遠位共著明なるものは 無く，エピ部では内側より少数の血管が進入 している.

3. 上腕骨

主栄養孔は骨体略々中头内側飞存し, 骨壁 を透位より近位へ向けや」斜飞貫く，動，静 脉亚んで進入するが，動，静脉別々の栄養孔 を通る例るあり，其の際は静脉は邀位奇りで 進入する.

骨䯣内の走行は他の骨に類似している.

近位骨端メ夕部内側腹面にメ夕静脉の進入 あり，エピ部では内側の骨頭部中央より進入 する細小動，静脉がある，遠位エピ，メ夕部 では内側より少数の動, 静脉が進入する.

4. 前腕骨

\section{1）尺骨}

主栄養孔は骨体前面の略々中头にて骨壁を や」遠位より近位に向け貫き，動，静脉亚九 で進入する。

学䯣内の走行は他の骨に於けると同様であ る.

メ夕部は遂近共，主として内側より 1〜2 们の動，静脉が入り，近位エピ部では内側腹 面, 运倍エピ部では内側より進入する。

口）橈 骨

主栄羡孔は骨体後面略々中头に存し，尺骨 の主栄盖孔よりや〉近位等りに存し，垂直又 はや」寀位より近位に向け骨壁を買き動, 静 脉並んで進大する。 
骨髄内の走行は他の骨に類似している.

骨端部のメ夕動, 静脉は遠, 近位共, 内側 より1ー2本が入る. 近位エピ部の進入は判 然とせず，遜位エピ部では内側より1〜2本 の動，静脉が進入する.

\section{第4章 考按並に釉话}

本編に於いても第 1 編同様, 各項目に分け て考按全に総括を記述する.

\section{1. 栄養孔}

\section{1) 部 位}

長管状骨の栄養孔の位置に関しては第 1 編 に既述の如く，一定せりとなす者と然らずと なす者ありて，予の所見では哺乳類は動物に 依り略々一定していたが鳥類, 陑棲類, 爬虫 類に於ては哺乳類に比し個体差が多く見られ， 特に雨棲類に於ては個体差甚しく種々の部位 飞栄養孔が存在する，両棲類飞次ぎ不定なる は爬虫類にして，鳥類にては略々一定の部位 に栄養孔が存在している。

又メタ，エピ部の太い血管に関しても鳥類 て於ては略々一定した部位より入るが，細小 なる血管に就いては一定していない，両棲類 に於てはエピ血管は一定部位にあるるメ夕血 管は不定であり，爬虫類にてはメ夕，エピ血 管共に一定した部位は認め難い。

口）骨壁貫通の状態

人体及び家鬼長管状骨々体部に於ける主栄 㵪血管の骨壁貫通の状態に関して種々の研究 あるは第 1 編に既述の通りで，一定の方向を 以て骨壁を貫くと云う説と，年令的に規則的

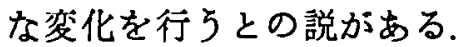

鳥類，雨棲類，爬虫類飞於ても哺乳類と同 様，長管状骨々体部に於ける栄養孔は骨壁を 斜めに貫く場合と韭直に頃く埸合あるる，前 者のうが多い，即ち鳥類に於ては下腿骨，上

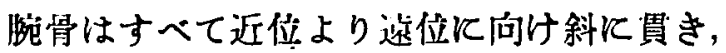

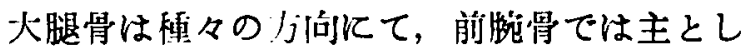
て近位より邀位へ问け䁈いている。

併し乍ら哺乳類飞比し個体差が多く，特飞 両棲類では全く一定しない，又爬虫類の亀で は大腿骨のみ蚞位より近位へ買き，他の骨で
は近位より遠位へ向け貫き，守宮はすへて遠 位より近位へ向け貫くが個体差が多い。

又栄養孔の骨辰軸との傾斜角度的野物差, 個体差が認められ一定していない。

次にメタ，エピ部に於ける血管飞関しても 各類共, 種々の方向にて入り一定していない.

八）栄養孔の数及び太さ

鳥類に於ては主栄養孔は普通 1 個である. 但し，脊黄脊大腿骨では $2 \sim 3$ 個存する例が 多く，又鷄腓骨飞於て子野脉の進入孔は 2 3 個ありて主要なるすのは不明である.

次飞耐棲類では栄養動，静脉が別々飞采養 孔を通過し為飞伊藤利の云う如く，栄養孔の 数も多く不定で 2〜3 個又はそれ以上の事す ある.

爬虫類でも同様栄養孔の数は一定せぬ例が 多い。

メタ，エピ部に於ける栄養孔の数は哺乳類 に於けると同様一定せず，又大なるメ夕静脉 幹は鳥類に於ては近位メ夕部《 1 個又は 2 個 あり，又遭位飞る1個のメ夕静脉孔を有する 例が多い。

両棲類飞於けるメ夕静脉幹恃太きすのは認 められず，すべて細小なるメ夕静脉のみであ り，その数も不定である.

爬虫類に於てもメ夕，エピ部の栄養孔の数， 及び位置は一定していない。

結局，下等類になる程栄養孔の位置は一定 せず，且その数，特に静脉孔の数は增加し， 又進入方向にも個体差がありて一定しなくな る.

\section{2. 栄養血管}

哺乳類に於ては栄養孔を通過する際の動, 静脉の状態は略々一定していたが，下等類に なると從い動，静脉同伴して同一の栄養孔を 通過することはむしろ少く，特に雨棲類飞於 ては全く同伴するととはない.

又骨体部主栄養孔内では，鳥類に於いてる 哺乳類汇比し静脉注細く, 鵎, 脊黄青の橈骨 飞於いては静脉の進入は見られず，動脉のみ が進入する例す認められた。

次に動，静脉の位置関係に関ししてる個体 
差ありて一定せず，多くの例では静脉、位の 事が多い，但し Venzlaf fii) と同様，九鳥大腿

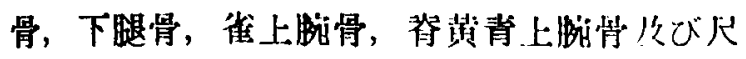
骨飞於ては動川水上位で入ることが多い．

闭楼類では動，静脉別值飞進入する為，1: 位，一位は問題とならない。

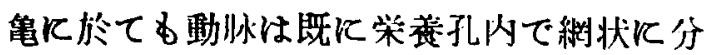
岐吻合し，静脉との関係状態は不定である。 守宮は動, 静脉並行して進人する例が多い,

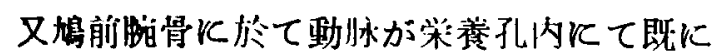
○分して居る例が認められた。

次にメタ、エピ部にては，馴類は哺乳類と 同しく動，静永背飞 1 つの栄羡孔を通過する ことは稀であり，大なる血管の進入に際して のみ動，静脉同伴して進入する，その際の 動, 静脉の位置的関係は一定していない，附 棲類，爬出類でも動，静脉闰伴することは涊 めなかつた。

又鳥類, 耐棲類では火滕の進入型式の 1 2 型が增加している。

3. 骨髄内血管の分枝及び走行

1) 動脉系

鳥類に於ては上腕骨は街を除き特異な走行 を示すが己に就いては後述する。

他の長管骨に於ては主栄養孔より骨髄内に 進入した動脉は上行, 下行の 々近位及び景位に向うこと，及び辞分岐部附

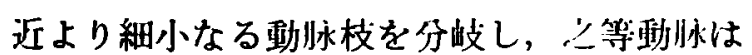
栄養孔附近の骨揭に分布することは哺乳類に 於けると同様である。

又上行, 下行枝共 $2 \sim 3$ 你して各分枝が亦, 犬々分岐を行つて分枝の数を增しつ」骨端に 向5は家鬼に於けると同様であり, Venzlaff の鳩於ける所兒と一致する。

但し九鳥，鶇の啡骨に肪ては前述の如く細小 なる動永が数ケ所より推入し，進入部附汀に 分布することが多く一定の走行型式は諰めら れない，又雀，春黄青等の小烏では動永分岐

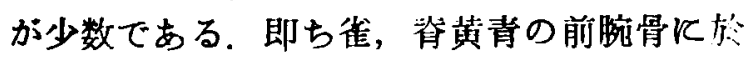
ては特に少数である。

野䏡枝間の吻合は細小動脉枝間に少数の吻 合が認められるが，九鳥に於ては家蒐に比し動

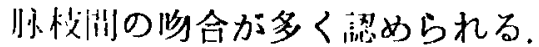

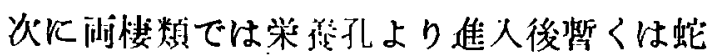
行を示し，やがて炏々と分岐を行い们校を出

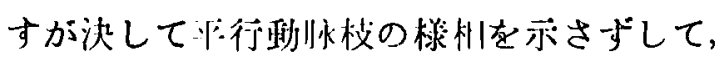
怙恔状に分岐するのが特唇である。

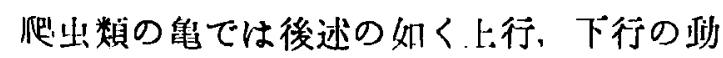

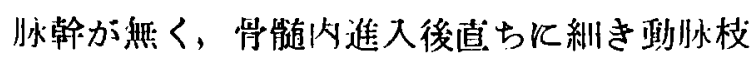
となり，吻合を篮ん飞行い理水網を形成する。 又守宾はや小照類似似た走行を示与。

口) 静杽水系

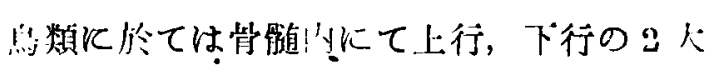

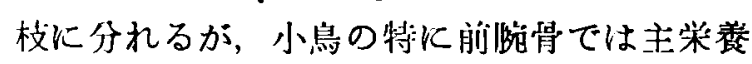

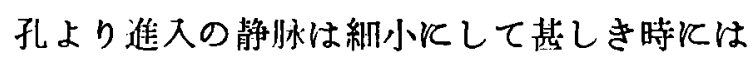
静永の進入を全く認め妨例もある。

即ち烏数に於ては近位又夕静脉の/jが县作 部より進入の静脉よりも太く，静怺としての 主役を演ずると思われる例が多く，人滕 マウス下腿骨に版て述へた如く，哺乳類にて む此の感を把かせる例を認めるが鳥頑に於て は特に著しく認められる。

いずれの場合にても静脉主幹は骨髄认を迁 曲を示しつ〉走行し，特に鴊の尺骨に於て蛇 行を示す。そして夫々近位及び寀位のメ夕静 脉と連絡吻合する。

又静咸は骨全長に亘り概ね同じ太さを有し て店り，且静汌幹の分岐は少く鳩，鴊等に於 て下行主幹静脉洞の: 3 飞分岐する少数例 を認める. 而して集合洞を四/うへ出すが小泉 颣ては集合洞は小且短であり, 数も家思比 し少数である。

集合洞は更と分岐して静汌洞となり複雑な る網状となるは唃乳類と同様である。

次に雨棲類でも静䏡の侵入孔が 2 個以上あ ることは既に述べたが; 骨髄内で互に主幹を 以て連絡吻合し，三由地”が述べた如く大腿骨 に然てあたか子静脉が肖体を横断しているが

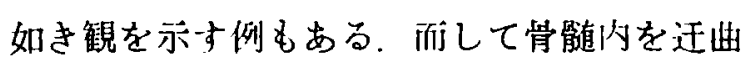
を示しつ」走行するが近位, 蚞位メ夕部の太 き静脉孔は認められない，又下腿骨，前腕骨 はこつの骨が憶合して居る為, 主幹静脉洞は 行して走行する。集合洞は业状飞て主幹 静永洞に注入している。 
爬出㓫では县能内進入後上行枝，下行枝飞 分れることなく骨髄内を 1 本の静脉主幹とし て走り，集合洞は認められず直ちと静汌洞網 に移行している.

4. 動永, 静脉の関係

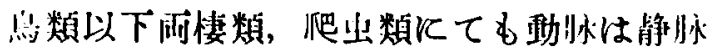

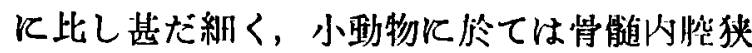
监の為野，静脉接近して走行し，九岛，鴊等の や小大なる動物では家鬼と略々類似した関係 を示す 即ち骨䯠進入後整くは坛，静永密接 するも間むなく分離して上々独自の走行を示 す.

又峏棲類でも骨髄内進入後暫くは動永が静 脉隹飞密着して走行する例が少数認められた 爬出類の暒では後述の如き特侏の状態を示 す.

5. 鳥類, 雨楼類, 爬虫類に坊ける特異的所 見

\section{1) 鳥 類}

鳥類に於て最も特異なるは上片骨の所見で ある．但し街では哺乳類に近き所見を呈する あ鳩，鴣，脊黄青では上斾骨の内部は中空で ある。その為静脉洞の発䏍は甚だ不良にして。 骨髄内壁に淮い嶋状又は地罒状飞存在する静 脉洞網を認めるのみであり，ただ骨端部近く に於ては骨体部に比しや小静脉洞が発達して いる.

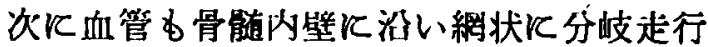
し，又骨内部の所々飞走る省梁に沿い血管が 尖行して后るのが観繁され，分岐せる血管の 数は洞省端部，特飞江位端飞於て多く譛め れる。

\section{口) 両悽類}

栄養孔の位置の不定なること，及びその数 る不定なることは既述した如くであるが，他 の特巽な点としては下腿骨に於ける所見があ る.

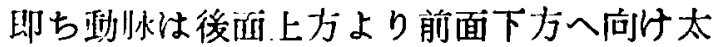
き動脉が骨体中央部を貫通して括り，骨䯣内 に方ミて上，下ミ方向飞動永枝を分岐する。こ の太き動汌の筫通は腓骨，胿骨の應着せる為，

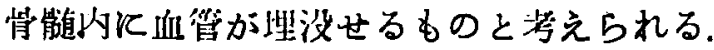

そと対し静脉は側方より絒き静脉が進入し，

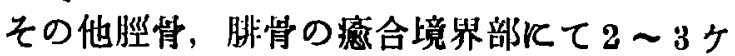
所から静永が斜上方又は斜下方へ向け情壁を

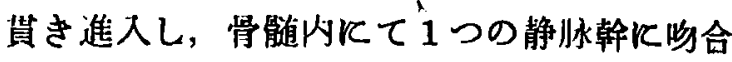
速絡する，又集合涧の分岐す哺乳類と哄り带: 状火分れて居る。

吏に特筫なるはエピの状態なるも之の詳細 は第 3 編飞記述する。

八）爬出類

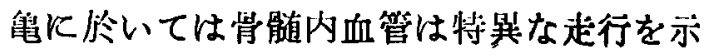
す。即ち栄養動永は主栄養孔内を通過の際飞 既飞 3 4 分し, 骨䯣内に入るや直ちに多く の細動脉枝飞分れ，動脉枝間の旺盛なる吻合 を行い，あたかる動浆網の如き観を呈する。 而して動脉網の内部を主幹静怺洞が走行し， その分畦たる静脉洞を介して動脉網と連絡吻 合する，従つて上行，下行主幹動脉枝，平行 動脉枝，集合洞等は認められない。

其の他舶, 守宮与哺乳類に比し栄養孔の部 位，及び数の不定なること多き蕾棲類と同 粎である。

\section{第 5 算 結 䛸}

1. 鳥類, 河棲類, 爬虫類の各々 $2 \sim 3$ 種 動物の長管状骨々膸の主幹血管に就き，主と してスパルテホルツ式逶明標本に依り研索し た.

2. 鳥類飞於ては大腿骨, 下腿骨, 前腕骨 は哺乳類と略々同様の走行を示すが，上脃骨 は街を除き骨は中空状態であり，骨漣は殆ん ぞ認められず，血管も特翼な走行を示す。

3. 峏棲類にては下腿骨, 前腕骨は禹骨瘾 合し，為に血管の走行は特異的であり，特に 下腿骨では骨体中央部を販通する太き動脉が 存在し, 骨䯣内通過の際上行, 下行の動怺枝 を分岐する。

4. 怇虫類に於て等宮はや小鳥類に類似す

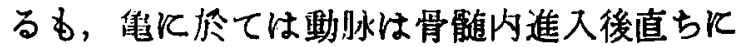
細動脉枝に分岐し，互に吻合を行い動脉網を 形成し，その中止を静永幹が走行する.

5. 種属の下等になるに従い栄養孔の位置, 数，栄委孔の進入角海及び栄篦孔通過の際の 
動, 静脉の位览的関保も個体差が増加する。

6. 楮風の下等になるに従い栄養動, 静将 が別々の栄養孔より進入することが多く, 又

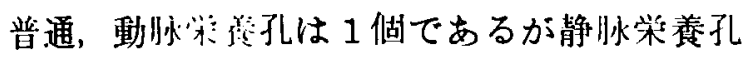
はっ湖以上のことが多くなる。
㨄第するにあたり終始御愁第なる御指導御校閵を 賜つた恩師本木教授花に大藤助教授に対し深甚の謝 意を表し，併せて Resin,タッタヘルカ注入法に関 し想ろなる御教示を睗りたる今川教授汇深湖する。

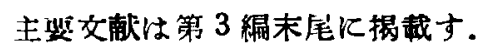

\section{写亲說明}

\begin{tabular}{|c|c|c|}
\hline 第 1 为 & 炻上拫学血管:系 & （涹明標本 \\
\hline 第 2 议 & 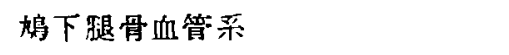 & （狳上 \\
\hline 第 3 略 & 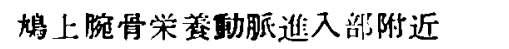 & （全 上 \\
\hline 第 4 約 & 沜前䛷骨血智:系 & '（全上 \\
\hline 第 5 図 & 棌 前 腕 骨 & （全 上 \\
\hline & 右側 勡脈系 & \\
\hline $6 \mathrm{~W}$ & 省上腕骨血管系 & （唀明標本 \\
\hline 7 湡 & 背黄青烧鸮上腕骨血驾: 系 & (余上 \\
\hline 第 8 図 & 基大跟骨血管采 & ( 定上 \\
\hline 第 9 必 & 基下腿骨血管采 & ( 全 上 \\
\hline $10 \mathbb{X}$ & 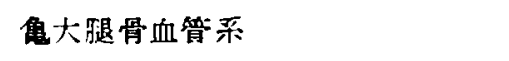 & ( 全 上 \\
\hline 11 圆 & 角大骨血管采弱拡大 & ( 소 \\
\hline & 守宮大骨上牛部血丽系 & ( 소 \\
\hline
\end{tabular}


第 1 図
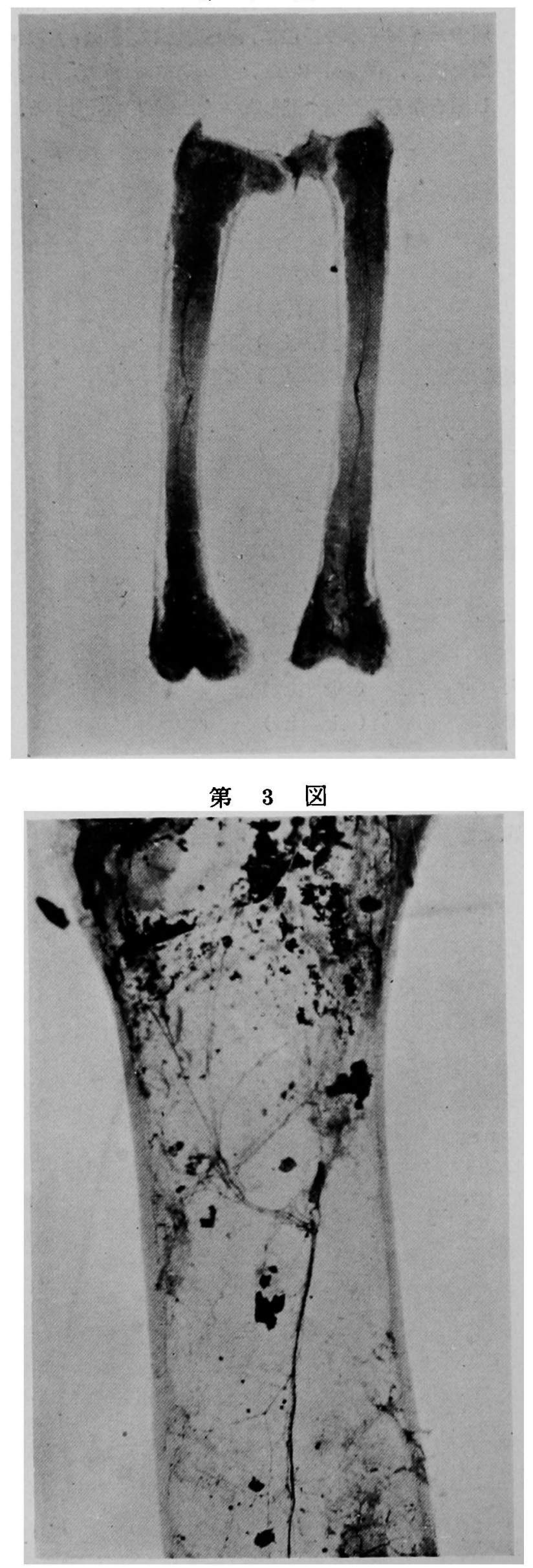

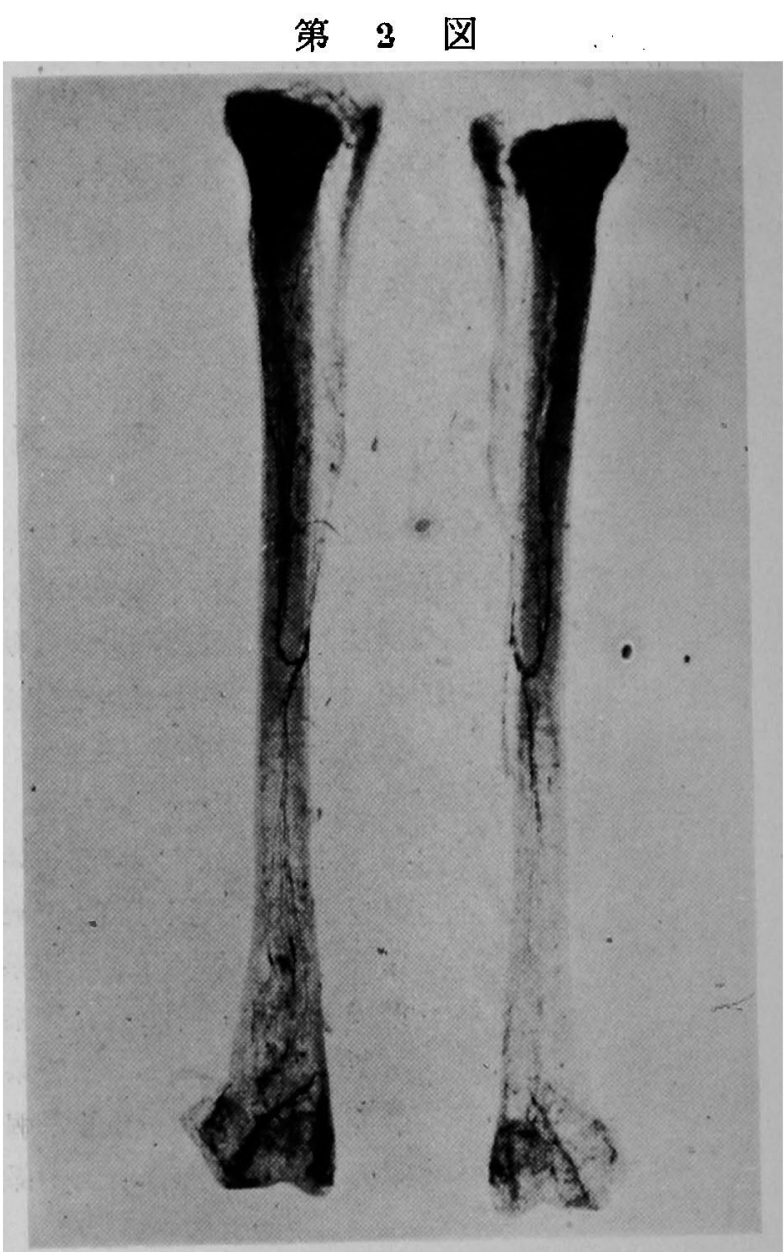

第 4 図

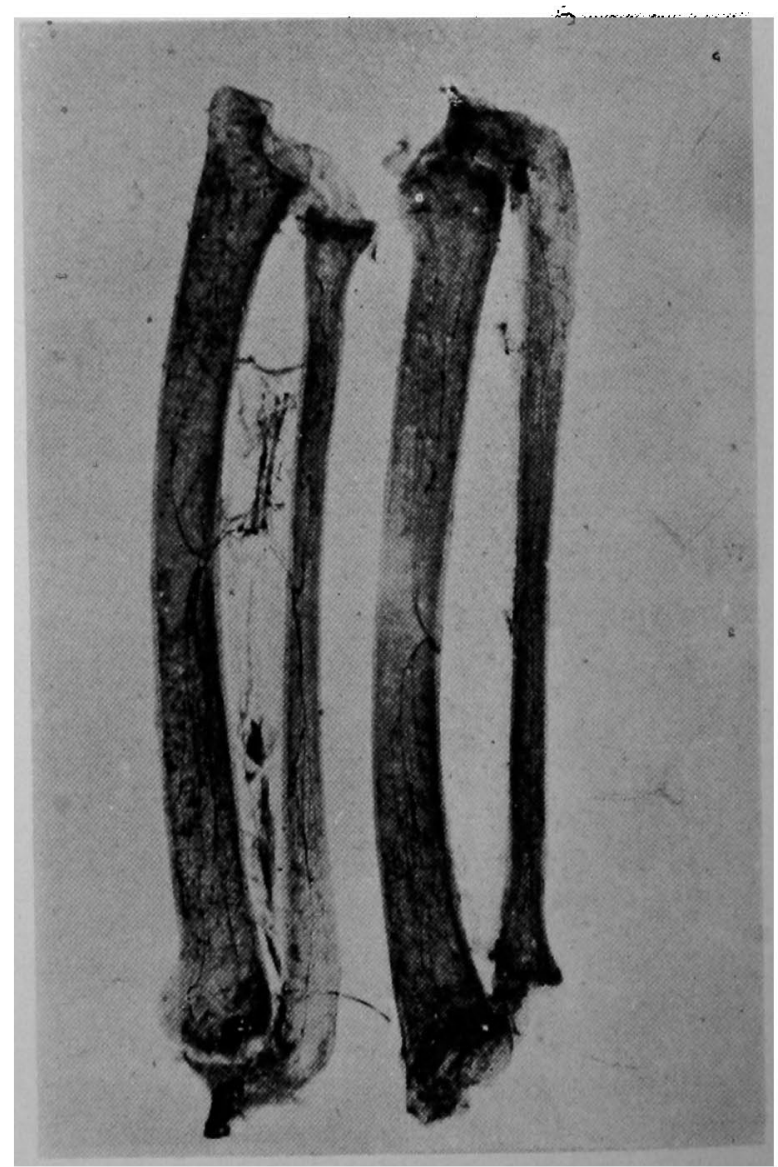


第 5 図

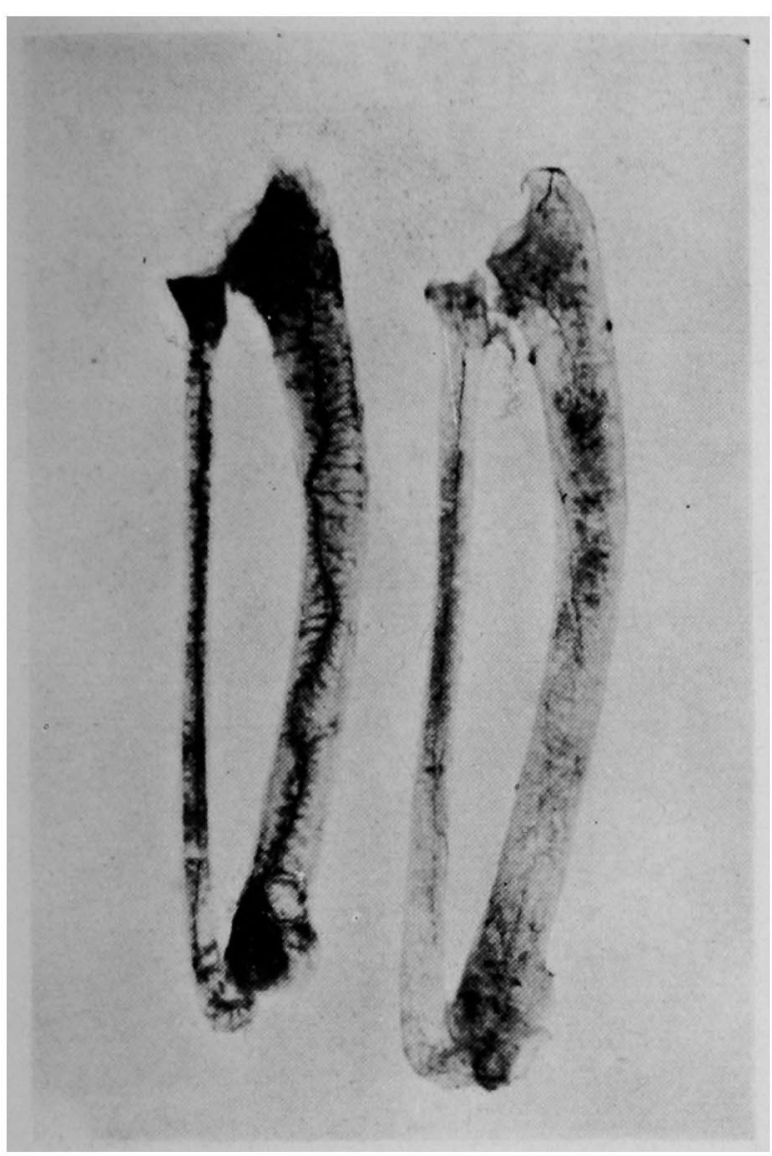

第 7 図

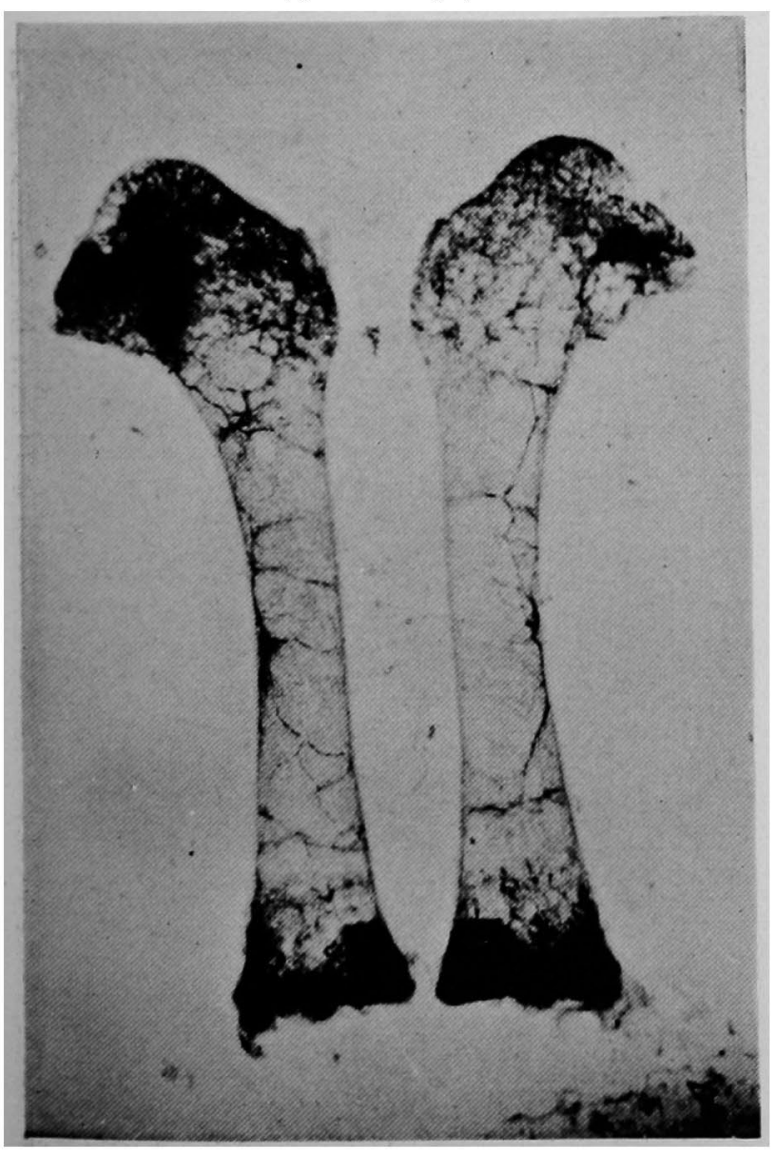

第 6 図

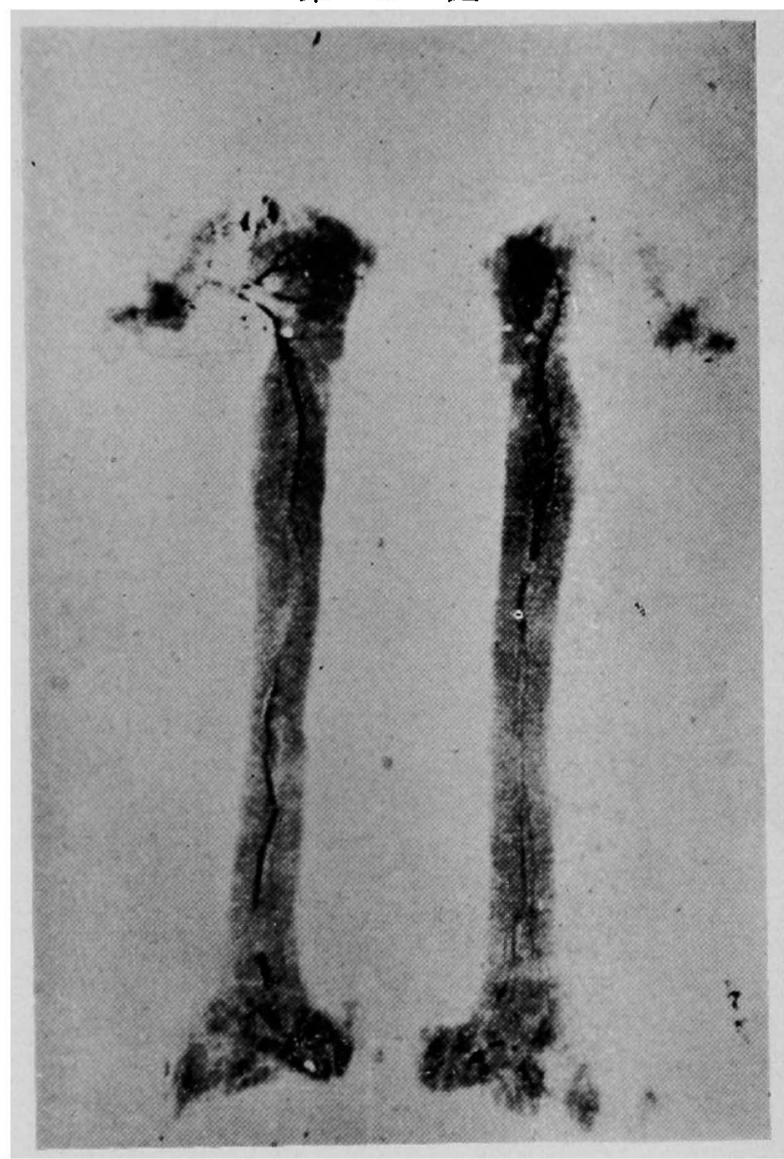

第 8 図

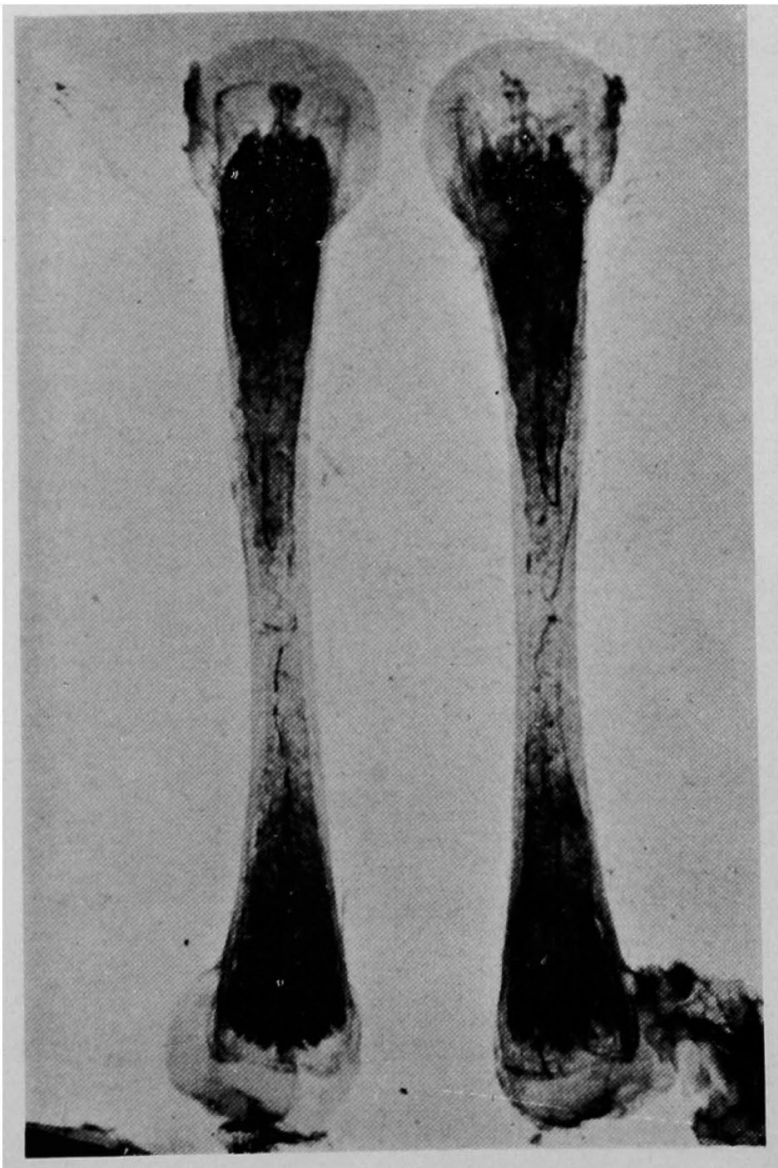


第 9 図

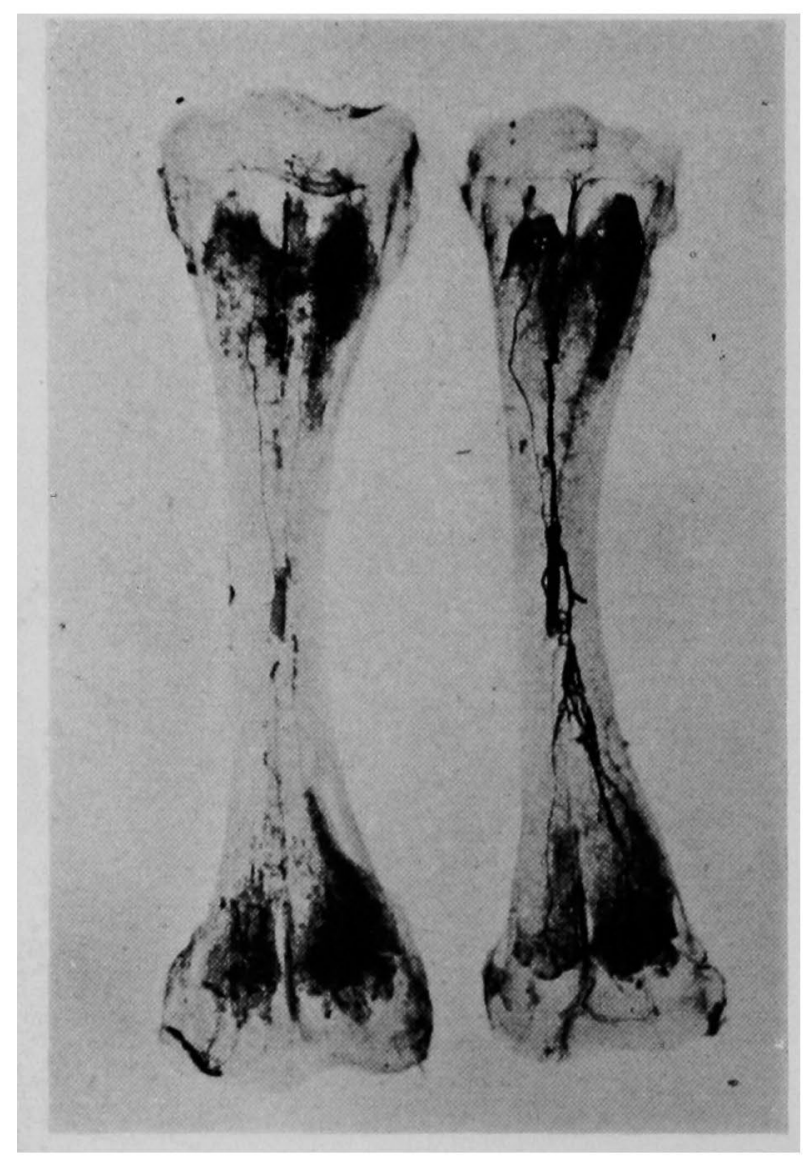

第 11 図

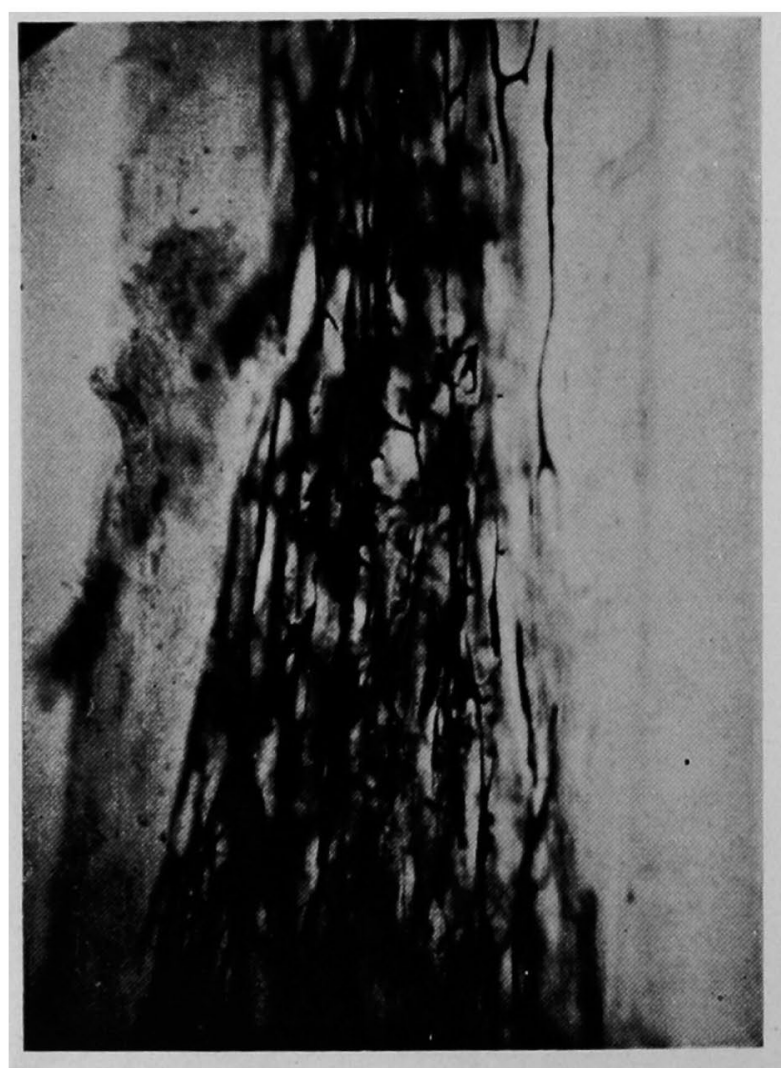

第 10 図

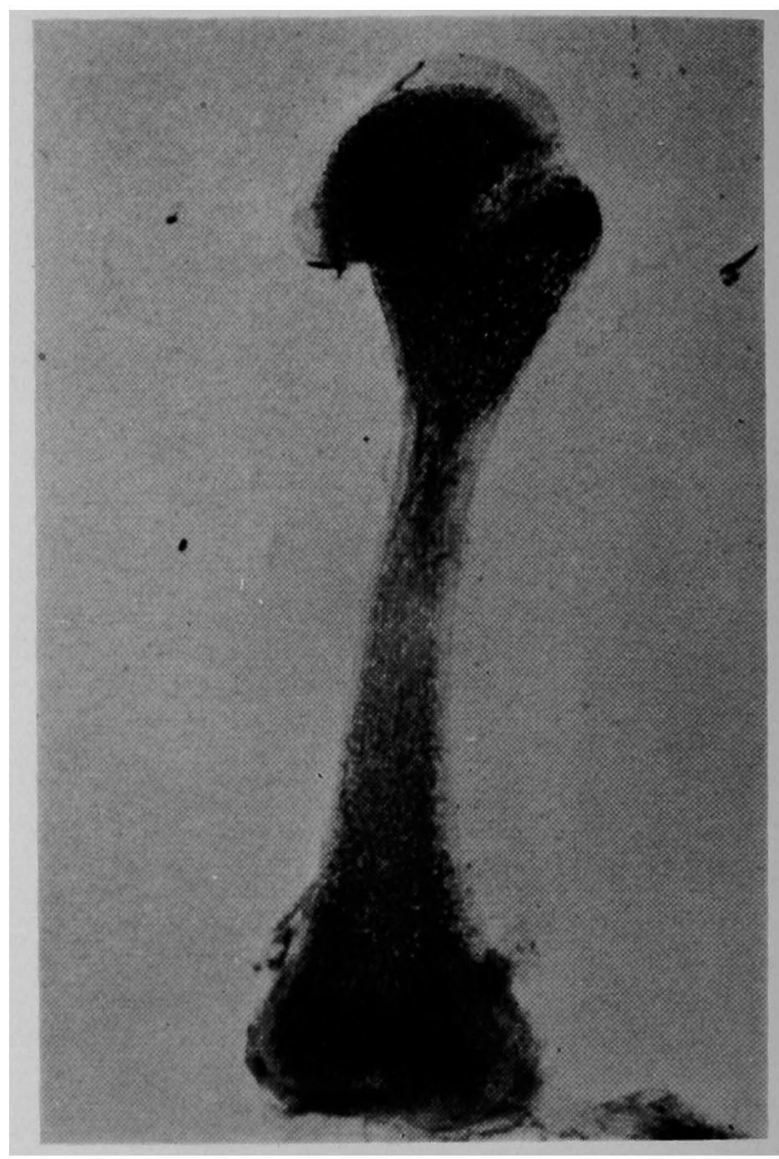

第 12 図

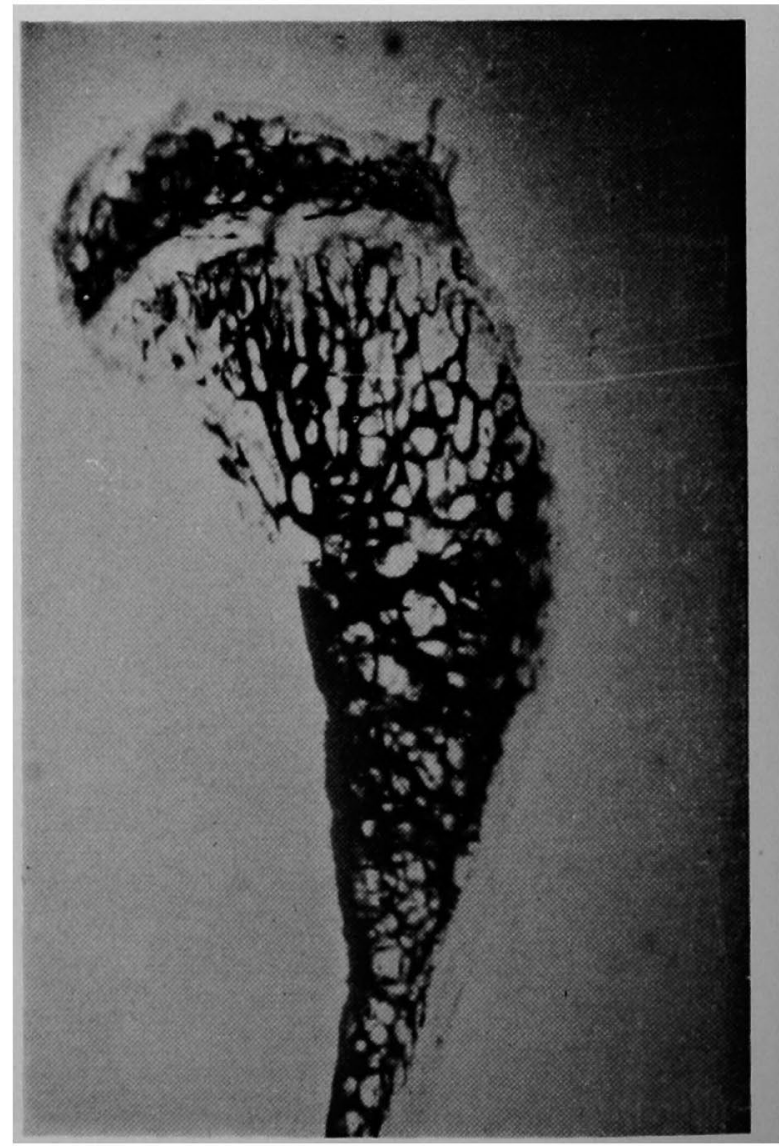

